\title{
Extracellular Matrix: Functions in the Nervous System
}

\author{
Claudia S. Barros, Santos J. Franco, and Ulrich Müller \\ The Scripps Research Institute, Department of Cell Biology, Dorris Neuroscience Center, La Jolla, \\ California 92037 \\ Correspondence: umueller@scripps.edu
}

\begin{abstract}
An astonishing number of extracellular matrix glycoproteins are expressed in dynamic patterns in the developing and adult nervous system. Neural stem cells, neurons, and glia express receptors that mediate interactions with specific extracellular matrix molecules. Functional studies in vitro and genetic studies in mice have provided evidence that the extracellular matrix affects virtually all aspects of nervous system development and function. Here we will summarize recent findings that have shed light on the specific functions of defined extracellular matrix molecules on such diverse processes as neural stem cell differentiation, neuronal migration, the formation of axonal tracts, and the maturation and function of synapses in the peripheral and central nervous system.
\end{abstract}

Extracellular matrix (ECM) glycoproteins are Ewidely expressed in the developing and adult nervous system. Tremendous progress has been made in defining the roles of specific ECM components in controlling the behavior of neurons and glia (Sanes 1989; Reichardt and Tomaselli 1991; Venstrom and Reichardt 1993; Milner and Campbell 2002; Nakamoto et al. 2004). Here, we will provide an overview of ECM functions in the nervous system, emphasizing recent findings that have shed light on the mechanisms by which ECM glycoproteins regulate such diverse processes as neural stem cell (NSC) behavior, neuronal migration, formation of axonal processes and their myelin sheets, and synapse formation and function.

\section{NEURAL STEM CELL BEHAVIOR AND NEURONAL MIGRATION}

NSCs give rise to neurons and glia, and the ECM provides a microenvironment that modulates NSC behavior (Perris and Perissinotto 2000; Sobeih and Corfas 2002; Zimmermann and Dours-Zimmermann 2008). Radial glial cells (RGCs) of the developing central nervous system (CNS) are a well-studied class of NSCs (Fig. 1) (Temple 2001; Fishell and Kriegstein 2003; Kriegstein and Noctor 2004; Noctor et al. 2007; Malatesta et al. 2008; Miller and Gauthier-Fisher 2009). RGCs are also precursors of neural progenitors maintained in the adult brain (Kokovay et al. 2008; Miller and

Editors: Richard Hynes and Kenneth Yamada

Additional Perspectives on Extracellular Matrix Biology available at www.cshperspectives.org

Copyright (C) 2011 Cold Spring Harbor Laboratory Press; all rights reserved; doi: 10.1101/cshperspect.a005108

Cite this article as Cold Spring Harb Perspect Biol 2011;3:a005108 


\section{C.S. Barros et al.}

A

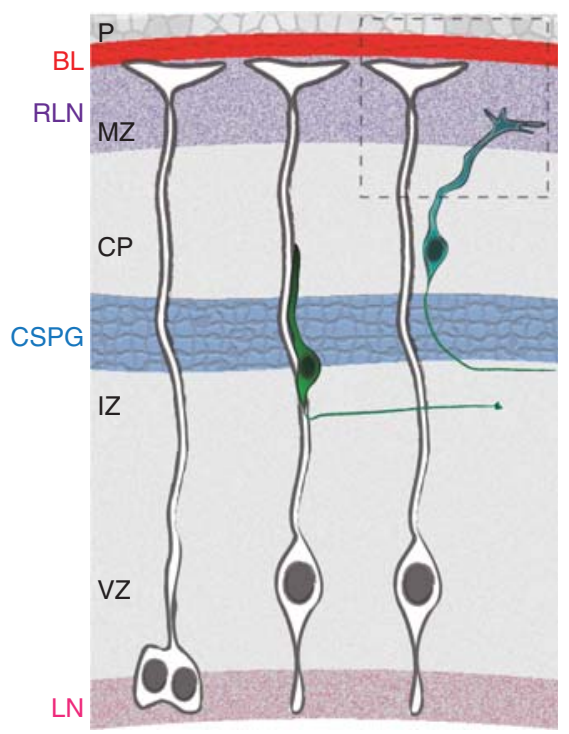

B

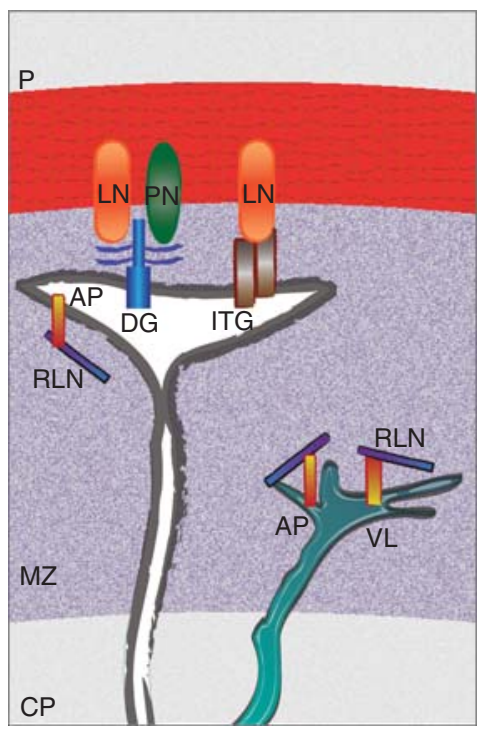

Figure 1. ECM molecules in the developing neocortex. (A) Overview of some ECM molecules found in the embryonic neocortex. Laminin (LN) is a major component of the basal lamina (BL) under the pia mater $(\mathrm{P})$ and is also found in the ventricular zone (VZ). Reelin (RLN) is secreted in the marginal zone (MZ) by CajalRetzius cells. Chondroitin sulfate proteoglycans (CSPGs) are concentrated in the subplate region above the intermediate zone (IZ). (B) Higher magnification schematic of the boxed region in (A). RGC endfeet interact with ECM molecules in the BL, such as LN and perlecan (PN), through the integrin (ITG) and dystroglycan (DG) receptors. Radial glia and neurons engage in reelin signaling via the ApoER2 (AP) and VLDLR (VL) receptors.

Gauthier-Fisher 2009). RGCs have a radial morphology, with apical processes contacting the ventricle and basal processes extending across the respective CNS structures (Fig. 1). Many neurons use basal RGC processes as a scaffold for migration. The ECM shapes the niche where NSCs reside, modulates their maintenance and differentiation, and influences migration of their progeny (Sobeih and Corfas 2002; Porcionatto 2006; von Holst 2008).

\section{Laminins}

The ECM forms a basal lamina (BL) surrounding the brain and blood vessels throughout the CNS (Timpl and Brown 1996; Erickson and Couchman 2000). In the neocortex, the BL at the pial surface is contacted by RGCs' endfeet (Fig. 1). A number of studies have shown that the pial BL is crucial for neocortical development. Removal of the BL leads to detachment of RGC fibers, affecting RGC survival and cortical lamination (Sievers et al. 1986; von Knebel Doeberitz et al. 1986; Sievers et al. 1994; Radakovits et al. 2009). Laminins are major components of the BL (Timpl et al. 1979) and are also present in the $\mathrm{VZ}$ of the developing neocortex (Campos et al. 2004; Lathia et al. 2007). Laminins promote the expansion, migration, and differentiation of NSCs in vitro (Drago et al. 1991; Liesi 1992; Liesi et al. 1992; Kearns et al. 2003; Campos et al. 2004; Flanagan et al. 2006; Hall et al. 2008; Ma et al. 2008; Silva et al. 2009; Pierret et al. 2010). Expression of several laminin subunits in cultured NSCs is dependent on the transcription factor RE1 Silencing Factor (REST) (Otto et al. 2007; Sun et al. 2008). REST regulates neurogenesis by repressing neurogenic genes in nonneuronal tissues (Schoenherr et al. 1996; Chen et al. 1998). REST-null embryonic stem cells have defects in cell adhesion, NSC generation and neuronal 
differentiation, phenotypes that can be rescued by exogenously added laminin (Sun et al. 2008). However, the effects of laminins on NSCs and the importance of the REST/Laminin interaction still await examination in vivo. Mice lacking laminin $\gamma 1$ die during embryogenesis (Smyth et al. 1999); those bearing a mutation affecting solely the laminin $\gamma 1$ nidogen-binding domain survive until birth and display disruptions of the pial $\mathrm{BL}$ and neuronal ectopias (Halfter et al. 2002). Inactivation of laminin $\gamma 1$ in a subset of cortical neurons causes cortical lamination defects (Chen et al. 2009). However, defects of NSC maintenance or differentiation have not been reported in these mutants.

In vivo evidence for a role of laminins in controlling NSC behavior comes from studies of their dystroglycan and integrin receptors. Human patients with mutations in enzymes that glycosylate dystroglycan show cortical neuronal ectopias (Yoshida et al. 2001; BeltranValero de Bernabe et al. 2002). Mice without dystroglycan in the CNS or bearing mutations in dystroglycan glycosyltransfserases display BL disruptions and neuronal migration defects (Grewal et al. 2001; Michele et al. 2002; Moore et al. 2002). Inactivation of $\beta 1$ integrins in RGCs results in abnormal neocortical lamination and fusion of cerebellar folia (Graus-Porta et al. 2001; Blaess et al. 2004). These abnormalities are caused by detachment of RGCs from the pia and disorganization of the pial BL and cortical marginal zone (MZ) (Fig. 1) (GrausPorta et al. 2001; Blaess et al. 2004; Radakovits et al. 2009). In the neocortex of $\beta 1$-deficient animals, neurons associate with intact RGCs and migrate, but form ectopias in the MZ (Graus-Porta et al. 2001). Similar phenotypes are observed in mice lacking the $\alpha 6$ integrin subunit or both $\alpha 6$ and $\alpha 3$, which heterodimerize with $\beta 1$ to form laminin receptors (Georges-Labouesse et al. 1998; De Arcangelis et al. 1999; Colognato et al. 2005). Deletion of $\beta 1$ integrin solely in migrating neurons results in normal neocortical lamination, indicating that abnormalities in neuronal migration are secondary to defects in RGCs (Graus-Porta et al. 2001; Belvindrah et al. 2007a).
Disruption of $\beta 1$ integrin function in the VZ by antibody injections leads to detachment of RGC apical processes (Loulier et al. 2009). Apical detachment of RGCs is also observed in mice lacking laminin $\alpha 2$ (Loulier et al. 2009). Thus, $\beta 1$ integrins and laminins appear to maintain both apical and basal RGC processes. In addition, loss of laminin $\gamma 1$ prevents neurons from migrating towards the MZ (Chen et al. 2009), a phenotype that differs from those resulting from loss of $\beta 1$ integrins, indicating that other surface receptors are involved. For example, $\beta 4, \beta 8, \alpha 3, \alpha 4$, and $\alpha 5$ integrins have been implicated in NSC development, neocortical lamination, and/or neuronal migration (Murgia et al. 1998; Mobley et al. 2009; Stanco et al. 2009; Marchetti et al. 2010). Furthermore, ECM molecules and integrins likely play context-dependent roles. For example, in the adult brain, $\beta 1$ integrins and laminins $\alpha 2 / \alpha 4$ are required for the formation of cell chains in the rostral migratory stream (RMS) (Belvindrah et al. 2007b).

\section{Proteoglycans}

Proteoglycans are prominently expressed in the nervous system ( $\mathrm{Gu}$ et al. 2007; Gu et al. 2009; Abaskharoun et al. 2010), and enzymatic digestion of chondroitin sulfate proteoglycans disrupts the development of NCSs in culture (von Holst et al. 2006; Gu et al. 2009). Yet, no major abnormalities have been described in the CNS of mice lacking proteoglycans, likely because of either functional redundancy or early embryonic lethality (Hartmann and Maurer 2001; Zimmermann and Dours-Zimmermann 2008). One exception is the BL component perlecan. Genetic ablation of perlecan results in exencephaly following massive BL disruptions, or in neuronal ectopias in mutant brains with less severe BL defects (Haubst et al. 2006; Giros et al. 2007). In the latter cases, cell cycle progression in NSCs is affected, likely because of decreased levels of sonic hedgehog (Giros et al. 2007). Interestingly, proliferation of granule cell precursors in the cerebellum is also affected in mice lacking $\beta 1$ integrins, a phenotype that is caused at least 
C.S. Barros et al.

in part by defective sonic hedgehog signaling (Blaess et al. 2004).

\section{Tenascins}

Tenascin-C (TN-C) is expressed in the CNS in regions of active neurogenesis (Bartsch et al. 1992; Jankovski and Sotelo 1996). Tenascin-R (TN-R) expression is prominent in myelinating glia, in subsets of interneurons and in the deepest layers of the olfactory bulbs (Saghatelyan et al. 2004; Huang et al. 2009). In NSCs in culture, TN-C facilitates the switch from production of neuronal to glial progenitors (Lillien and Raphael 2000; Garcion et al. 2004; Liao et al. 2008), whereas TN-R inhibits migration of NSC-derived neurons (Huang et al. 2009). In vivo, $\mathrm{TN}-\mathrm{C}$ regulates myelinating glial lineage development and glomerulogenesis in the olfactory bulbs (OBs) (Garcion et al. 2001; Treloar et al. 2009). TN-R promotes detachment of chain-migrating neuroblasts in the RMS and their migration within the OBs. Interestingly, $\mathrm{OB}$ expression of TN-R is activity-dependent and reduced on odor deprivation (Saghatelyan et al. 2004).

\section{Reelin}

Reelin is one of the best-studied ECM glycoproteins in the CNS. During development, reelin is secreted by specific cell types in laminated brain structures, including the neocortex (Fig. 1). Reelin binds to the lipoprotein receptors ApoER2 and VLDLR (D'Arcangelo et al. 1999), which are expressed by migrating neurons and RGCs (Luque et al. 2003). ApoER2 and VLDLR bind to the adaptor protein Dab1, which is phosphorylated by Src-family kinases on reelin binding to its receptors (Howell et al. 1999; Arnaud et al. 2003). Phosphorylated Dab1 recruits signaling molecules including PI3K (Bock et al. 2003), Crk/CrkL (Ballif et al. 2004; Chen et al. 2004; Huang et al. 2004), and Lis1 (Assadi et al. 2003). Mutations in reelin signaling in humans cause lissencephaly and cerebellar hypoplasia (Hong et al. 2000), and in mice severe CNS abnormalities characterized most notably by severe lamination defects in the cerebellum, hippocampus and neocortex (Mariani et al. 1977; Caviness and Korde 1981; Caviness 1982; Goffinet 1983; Goffinet et al. 1984; Hoffarth et al. 1995). Defective neocortical lamination is caused by failure of newborn neurons to move past their predecessors, creating a disorganized cytoarchitecture lacking the typical inside-out layering pattern of the normal neocortex. Because the number and types of neocortical neurons generated appears unaffected in reeler mutants (Caviness 1973), reelin is thought to primarily control migration. However, the cellular mechanism by which reelin regulates cell positioning is not known. Reelin has variably been proposed to be a chemoattractant (Gilmore and Herrup 2000), repellent (Ogawa et al. 1995; Schiffmann et al. 1997), stop (Sheppard and Pearlman 1997), or detachment (Sheppard and Pearlman 1997; Dulabon et al. 2000; Sanada et al. 2004) signal for migrating neurons.

A role for reelin as a detachment signal is supported by the observation that postmigratory neurons remain associated with RGC fibers in reeler mice, creating a "traffic jam" (PintoLord et al. 1982), and by studies suggesting that reelin down-regulates integrin-mediated adhesion, allowing migrating neurons to detach from the RGC scaffold (Dulabon et al. 2000; Sanada et al. 2004). However, when reelinresponsive and nonresponsive neurons coexist, wild-type cells migrate normally (Sanada et al. 2004; Olson et al. 2006; Hammond et al. 2010). Genetic studies also do not support a role for integrins on migrating neurons in reelin signaling (Belvindrah et al. 2007a). In addition, the detachment hypothesis does not account for migration defects in early-born neurons, which do not migrate along RGCs (Nadarajah et al. 2001). Finally, cell-autonomous perturbations of reelin signaling in radially migrating neurons block their movement and addition of recombinant reelin to slice cultures from reeler mice restores migration (Jossin et al. 2004; Olson et al. 2006; Young-Pearse et al. 2007; Hashimoto-Torii et al. 2008), indicating that reelin promotes motility. Because recent observations show that neocortical neurons migrate by glia-dependent and glia-independent modes 
(Nadarajah et al. 2001), it has been proposed that reelin stimulates detachment of neurons from RGCs as well as glia-independent migration (Luque et al. 2003; Cooper 2008).

Studies demonstrating cross talk between reelin and other signaling pathways, such as integrins (Dulabon et al. 2000; Calderwood et al. 2003; Sanada et al. 2004), Notch (Hashimoto-Torii et al. 2008), amyloid precursor protein (Young-Pearse et al. 2007) and thrombospondins (Blake et al. 2008) indicate that reelin is part of a complex developmental paradigm with distinct mechanisms of action in different brain regions (Trommsdorff et al. 1999; Benhayon et al. 2003; Beffert et al. 2006; Hack et al. 2007; Forster et al. 2010).

\section{AXONAL GROWTH AND MYELINATION}

Wiring of the nervous system depends on a coordinated sequence of events, including axon growth to precise targets and their subsequent myelination. CNS myelination is performed by oligodendrocytes, whereas Schwann cells myelinate peripheral nerves (Sherman and Brophy 2005; Simons and Trajkovic 2006). The ECM is crucial for axon formation and myelination (Colognato et al. 2005; Chernousov et al. 2008) (Fig. 2), and is a component of glial scar tissue at sites of CNS injury (Rolls et al. 2009).

\section{Laminins}

Some of the first results implicating ECM molecules in nervous system development showed that laminins promote neurite outgrowth in an integrin-dependent manner (Calof and Reichardt 1985; Lander et al. 1985a; Lander et al. 1985b; Hall et al. 1987; Tomaselli and Reichardt 1988). These findings have been extended by others (e.g., Gomez and Letourneau 1994; Luckenbill-Edds 1997; Esch et al. 1999; Menager et al. 2004). Laminins have also been implicated in axonal guidance in vivo. For example, ablation of Drosophila laminin A results in pathfinding defects in sensory nerves (Garcia-Alonso et al. 1996). In Xenopus, laminin-1 modulates growth cone behavior of retinal neurons, converting the attraction cue provided by netrin-1 into repulsion (Hopker et al. 1999). In mice, laminin $\gamma 1$ deficiency results in abnormal branching of myelinated axons from the corpus callosum (Chen et al. 2009). The mutants also show abnormal neuronal migration (see below), impaired activation of integrin downstream effectors like focal adhesion kinase and paxillin, and disrupted AKT/GSK-3 $\beta$ signaling, which has been implicated in neurite growth (Yoshimura et al. 2005). The exact mechanisms underlying these abnormalities await investigation.

In the peripheral nervous system (PNS), Schwann cells are surrounded by a basal lamina (BL) that contains laminin $2(\alpha 2 \beta 1 \gamma 1)$, laminin $8(\alpha 4 \beta 1 \gamma 1)$, and laminin $10(\alpha 5 \beta 1 \gamma 1)$ (Feltri and Wrabetz 2005). Schwann cells migrate into peripheral nerve and use a mechanism known as radial sorting to establish a 1:1 association with each larger diameter axon (Shy 2009) (Fig. 2). Human patients suffering from congenital muscle dystrophy (MDC) lack laminin $\alpha 2$ and develop demyelinating peripheral neuropathy (Shorer et al. 1995; Di Muzio et al. 2003). In laminin $\alpha 2$-deficient mice, sorting and axon myelination are impaired following reduced Schwann cell proliferation and inability to extend myelin sheets (Bray et al. 1977; Helbling-Leclerc et al. 1995; Feltri et al. 2002). These defects are most prominent in nerve roots. Conversely, loss of laminin $\alpha 4$ leads to axonal sorting defects that are pronounced in distal nerve; when both laminin $\alpha 2$ and $\alpha 4$ are missing, all axon segments are affected (Wallquist et al. 2005; Yang et al. 2005). Similarly, mice lacking laminin $\gamma 1$ in Schwann cells show decreased Schwann cell proliferation, differentiation, and survival, radial sorting impairment, hypomyelination and reduced nerve conduction velocity (Yu et al. 2005; Yu et al. 2007). Mice lacking $\beta 1$ integrin in Schwann cells show radial axonal sorting defects and hypomyelination, but normal Schwann cell proliferation and survival (Feltri et al. 2002 ), suggesting that $\beta 1$ integrins only mediate some laminin functions. Dystroglycan is mainly expressed postnatally in Schwann cells but is another crucial laminin receptor. Dystroglycan-null mice have abnormally folded 


\section{C.S. Barros et al.}

A

$\begin{array}{ccc}\text { Immature } & \text { Myelinating } \\ \text { OPC } & \text { oligodendrocyte } & \text { oligodendrocyte }\end{array}$

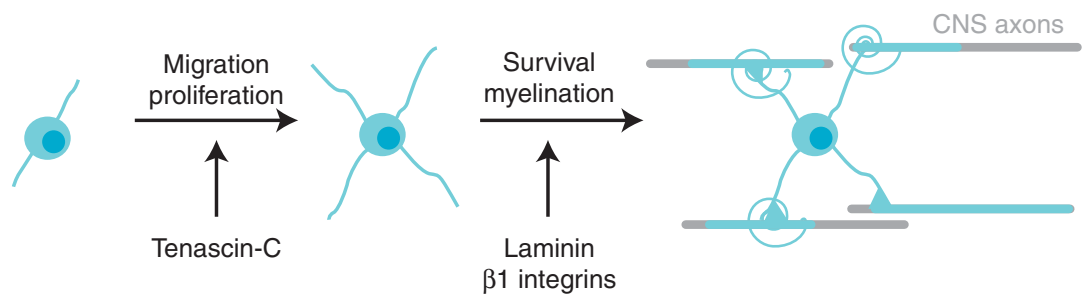

B

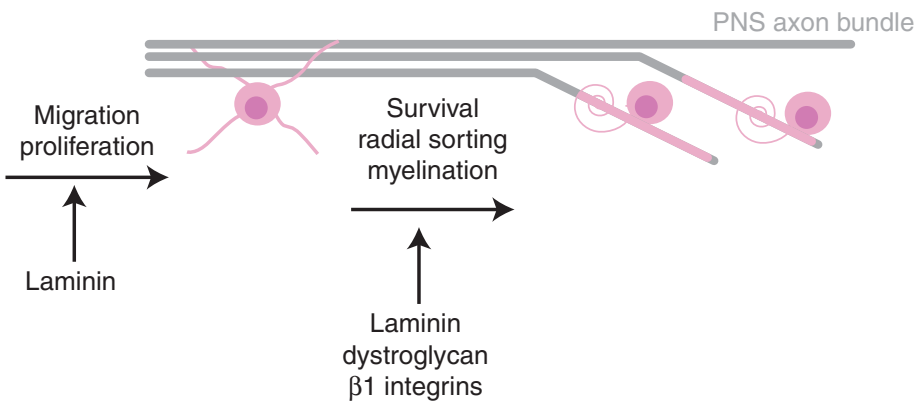

C

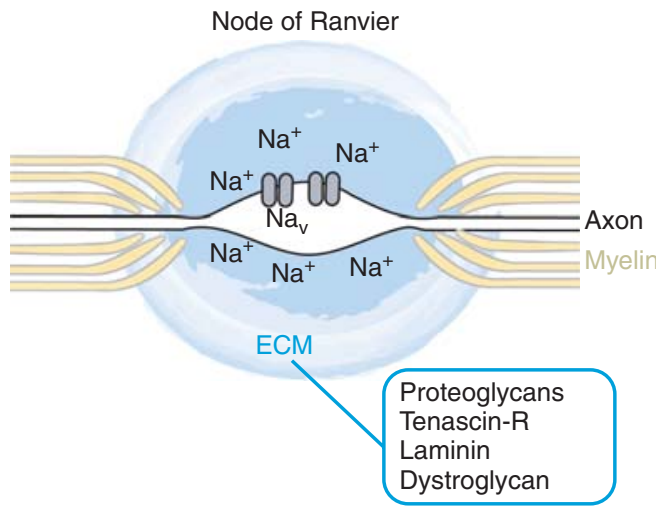

Figure 2. ECM and myelination. (A) Oligodendroglia differentiate in sequential stages to generate mature oligodendrocytes. Each oligodendrocyte myelinates several CNS axons. Tenascin- $C$, laminin, and their $\beta 1$ integrin receptors play roles at different developmental stages, as indicated. (B) Schwann cells myelinate peripheral nerves. Immature Schwann cells sort out axonal bundles to individually myelinate each axon. Laminin regulates all stages of Schwann cell development, whereas dystroglycan and $\beta 1$ integrin receptors control axonal sorting and myelination. $(C)$ The ECM surrounding nodes of Ranvier may regulate the local concentration of cations and clusters voltage-gated sodium channels, which allow for saltatory electrical conductivity. Several proteoglycans, tenascin- $\mathrm{R}$, laminin and dystroglycan contribute to the formation of nodal matrices. $\mathrm{Na}_{\mathrm{v}}$, voltage-gated channel; $\mathrm{Na}^{+}$, sodium cations. 
myelin and reduced clustering of sodium channels at the nodes of Ranvier (Saito et al. 2003).

In the CNS, oligodendrocytes derive mainly from precursors residing in the ventral VZ and ganglionic eminences. They proliferate and migrate before becoming mature myelinating cells (Bradl and Lassmann 2010). Oligodendrocytes are not associated with a BL and each cell extends multiple sheets able to myelinate several axons (Colognato et al. 2005; Simons and Trotter 2007) (Fig. 2). Expression of laminins correlates with the onset of CNS myelination (Colognato et al. 2002; Colognato et al. 2005), and varied degrees of defects have been found in white matter tracts of patients suffering from MDC (Caro et al. 1999; Leite et al. 2005). Mice lacking laminin $\alpha 2$ have a developmental delay in oligodendrocyte maturation, resulting in hypomyelination (Chun et al. 2003; Relucio et al. 2009). The degree of developmental delay is region-specific, which may reflect different laminin $\alpha 2$ requirements (Relucio et al. 2009). Abnormalities in Fyn signaling, which is modulated by laminins in cultured oligodendrocytes, were observed in the mutant brains, suggesting one explanation for the temporary stall in oligodendrocyte differentiation (Colognato et al. 2004; Relucio et al. 2009). Interestingly, $\beta 1$ integrins not only affect PNS but also CNS myelination (Relvas et al. 2001; Barros et al. 2009). Deletion of $\beta 1$ integrins in the CNS results in thinner myelin sheaths in several regions, and cultured oligodendrocytes require $\beta$ lintegrin signaling via Akt to extend myelin sheets (Barros et al. 2009).

\section{Proteoglycans}

A major obstacle for regeneration after CNS injury is the axon growth-inhibitory activity of the glial scar (Rolls et al. 2009). Chondroitin sulfate proteoglycans (CSPGs) are main scar components and found up-regulated in injured rat brains and spinal cords (Silver and Miller 2004; Galtrey and Fawcett 2007). In vitro, phosphacan and all soluble hyaluronan-binding CSPGs (aggrecan, versican, neurocan, and brevican) inhibit axonal growth (Bandtlow and Zimmermann 2000; Yamaguchi 2000). Enzymatic digestion of CSPGs reduces their inhibitory activity (McKeon et al. 1995; Smith-Thomas et al. 1995) and promotes axon regrowth and functional recovery after spinal cord injury (Moon et al. 2001; Bradbury et al. 2002; Yick et al. 2003; Caggiano et al. 2005; Bai et al. 2010).

Proteoglycans have been proposed to participate in the assembly of the extracellular meshwork surrounding nodes of Ranvier (Fig. 2). Differential proteoglycan expression is observed in central versus peripheral nodes of Ranvier and between large and small diameter CNS axons (Peles and Salzer 2000; MelendezVasquez et al. 2005). In brevican-deficient mice, the CNS nodal matrix composition is reorganized; components typically associated with large diameter nodes, such as phosphacan and TN-R, no longer show a diameter-dependent association (Bekku et al. 2009). Molecular alterations of the nodal ECM are also observed in a mouse model lacking the versican splice variant V2 (Dours-Zimmermann et al. 2009). However, no conduction velocity defects were obvious in either of these mutants (Bekku et al. 2009; Dours-Zimmermann et al. 2009). In contrast, loss of brain-specific hyaluronan-binding link protein 1 (Bral1), which also localizes over nodes of Ranvier and forms complexes with brevican and versican V2, inhibits the stabilization of nodal matrices and is thought to impair accumulation of cations at nodes, resulting in slow conduction velocities (Bekku et al. 2010).

\section{Tenascins}

TN-R and TN-C have been implicated in neurite growth. In vitro, both TNs promote or retard neuritogenesis, depending on the neuronal cell types (Faissner and Kruse 1990; Pesheva et al. 1993; Taylor et al. 1993; Lochter et al. 1994; Rigato et al. 2002; Mercado et al. 2004). Although no axonal pathfinding defects have been reported in TN-R mutant mice, TN-R acts as a repellent for optic axons in zebrafish (Becker et al. 2003; Becker et al. 2004). In the $\mathrm{OB}, \mathrm{TN}-\mathrm{C}$ is an inhibitory boundary molecule, preventing axonal growth of sensory neurons before glomerulogenesis (Treloar et al. 2009). 
C.S. Barros et al.

TN-R and TN-C also regulate myelinating glia and axonal function (Fig. 2). TN-R is expressed in immature and mature oligodendrocytes, and $\mathrm{TN}-\mathrm{C}$ in oligodendrocyte precursor cells (OPCs) (Fuss et al. 1993; Czopka et al. 2009). TN-R facilitates OPC differentiation in vitro, whereas oligodendrocyte maturation is reduced on TN-C substrates. Conversely, loss of TN-C accelerates oligodendrocyte differentiation (Pesheva et al. 1997; Garwood et al. 2004; Czopka et al. 2009). Despite these opposing effects, TN-C and TN-R inhibit extension of myelin sheets by oligodendrocytes in vitro (Garcion et al. 2004; Czopka et al. 2009). However, neither TN-R nor TN-C knockout mice show myelination abnormalities (Kiernan et al. 1999; Weber et al. 1999). TN-C mutants have increased migration and reduced rate of OPC proliferation, but decreased cell death in myelination areas likely corrects for any reduction in oligodendrocyte density (Garcion et al. 2001). Interestingly, in TN-R knockout mice, expression of phosphacan along white matter tracts is perturbed and axonal conduction velocity is decreased (Weber et al. 1999), suggesting that TN-R may have an essential function in ECM assembly at nodes of Ranvier.

\section{Thrombospondin Type-1 Repeat Proteins}

ECM proteins sharing thrombospondin type-1 repeats regulate axon outgrowth and guidance. These include members of the thrombospondin (TSP) family, F-spondin, SCO-spondin, and others (Adams and Tucker 2000; Tucker 2004; Meiniel et al. 2008). TSP isoform- 1 is the bestcharacterized member of the TSP family and is secreted by astroglia. TSP1 promotes neurite outgrowth in many types of cultured neurons (Neugebauer et al. 1991; O'Shea et al. 1991; Osterhout et al. 1992). This effect is mediated by $\beta 1$ integrins in retinal and sympathetic neurons (Tomaselli et al. 1990; DeFreitas et al. 1995). TSP 1 is also detected along white matter tracts and promotes migration of OPCs (ScottDrew and ffrench-Constant 1997). Additionally, TSP1 levels are up-regulated at sites of injury, and correlate with the capacity of axons to regenerate (Moller et al. 1996; Hoffman and O'Shea 1999a; Hoffman and O'Shea 1999b).

F-spondin is expressed in the floor plate and in developing peripheral nerves. It inhibits adhesion and influences migration of neural crest cells, promotes commissural axon outgrowth, and acts as a contact-repellent molecule for embryonic motor neurons (Klar et al. 1992; Burstyn-Cohen et al. 1998; BurstynCohen et al. 1999; Debby-Brafman et al. 1999; Tzarfati-Majar et al. 2001). F-spondin is also thought to influence repair in injured peripheral sensory neurons (Burstyn-Cohen et al. 1998). SCO-spondin is secreted by ependymal cells of the subcommissural organ (SCO) in the developing vertebrate brain (Gobron et al. 1996; Goncalves-Mendes et al. 2003; Meiniel et al. 2008). TSR motifs of SCO-spondin induce neurite extension in neuronal cell lines in a $\beta 1$-integrin-dependent fashion; immunohistochemical evidence suggests it may control axonal development in vivo (Bamdad et al. 2004; Caprile et al. 2009; Hoyo-Becerra et al. 2010).

\section{Netrins and Slits}

The secreted molecules netrins and slits are part of two of the major protein families with crucial roles in axonal outgrowth and guidance. They provide instructive cues repelling or attracting axons depending on the repertoire of receptors presented at the surface of the neuronal growth cones and the activated intracellular signaling pathways. Netrins and slits also function in a variety of other processes within and outside the CNS, controlling cell adhesion, migration and polarity (Killeen and Sybingco 2008; Bradford et al. 2009; Ypsilanti et al. 2010).

Netrins are evolutionary related to the ECM molecule laminin and contain binding sites for heparan sulfate proteoglycans (HSPG), glycolipids and the integrins $\alpha 3 \beta 1$ and a6 $\beta 4$ (Bradford et al. 2009). The first identified netrin ortholog, Unc6, was found in Caenorhabditis elegans. Unc6 mutants showed axon guidance defects and an uncoordinated (Unc) crawling phenotype (Hedgecock et al. 1990). Netrins were then found in many other organisms including Drosophila, zebrafish and mammals. 
In vertebrates, the netrin family comprises the secreted netrin-1, netrin-3, and netrin-4 proteins and the glycosylphosphatidylinostol (GPI)membrane anchored netrins G1 and G2 (reviewed in Cirulli and Yebra 2007; Bradford et al.2009). Netrins are dynamically expressed in the developing CNS and in all species described so far netrin-1 is secreted by midline cells. The chemoattractant effects of netrin-1 are mediated through axonal receptors of the deleted in colorectal cancer (Dcc) family, which include the vertebrate Dcc and neogenin, the C. elegans UNC40 and the Drosophila Frazzled (Fra) proteins (Chan et al. 1996; Keino-Masu et al. 1996; Kolodziej et al. 1996). More recently, the Down syndrome cell adhesion molecule (Dscam) has also been shown to act as a netrin receptor promoting axonal attraction (Ly et al. 2008). Repulsive netrin-1 effects are mediated solely through Unc5 receptors or in combination with Dcc (Hong et al. 1999; Keleman and Dickson 2001). Netrin-1 acts both as a shortrange and a long-range guidance cue and is particularly significant for the steering of comissural axons. For example, mouse mutants for netrin-1 or Dcc completely lack the corpus callosum and hippocampal comissure, among defects in numerous other axonal tracts (reviewed in Barallobre et al. 2005).

The first member of the slit family was identified in Drosophila as a midline glia secreted protein (Kidd et al. 1999), but slits have since been discovered in several species (Ypsilanti et al. 2010). In mammals there are three slit genes (Slit1-3), all of which are expressed in the CNS (Itoh et al. 1998). Slits are glycoproteins that function as ligands for Roundabout (Robo) receptors. They act as major axonal repulsion cue and also inhibit axonal attraction (Stein and Tessier-Lavigne 2001; Killeen and Sybingco 2008; Ypsilanti et al. 2010). There are three Robo proteins in the CNS of Drosophila and of most vertebrates (Robo/Robo1, Leak/Robo2, and Robo3). Yet, Robos are not the only receptors for slits and vice-versa. For example, the EVA-1 transmembrane protein functions as a SLT-1/slit co-receptor in C. elegans and the interaction of HSPGs with slit proteins is required or potentiates their activity in some axonal tracts ( $\mathrm{Hu} 2001$; Piper et al. 2006; Fujisawa et al. 2007; Seiradake et al. 2009). As for netrin/Dcc, slit/Robo signaling is also essential for the establishment of many axonal tracts. For instance, mouse mutants for both Slit1 and Slit2 show axon guidance errors in a variety of pathways, including the corticofugal, callosal, and thalamocortical tracts (Bagri et al. 2002).

During development, the netrin and slit pathways are best known for their function in dorsal-ventral axonal guidance but they also play a role in anterior-posterior and longitudinal guidance (Killeen and Sybingco 2008). The two guidance cues are often tightly coordinated as exemplified in many studies of midline crossing by commissural axons in vertebrates and invertebrates. In brief, commissural axons are at first attracted towards the midline by netrin and are insensitive to the slit repulsive cue because its reception by the growth cone is transiently repressed. In flies, this negative regulation of the slit-Robo pathway is performed by commissureless, which is only transiently expressed in precrossing commissural neurons, ensuring that at that stage newly synthesized robo proteins are not trafficked to the growth cones but instead are targeted for degradation (Keleman et al. 2002; Keleman et al. 2005). In mice, this function is provided by the Robo3.1 isoform, which is also transiently expressed in precrossing neurons, although the precise mechanism involved is not yet clear (Chen et al. 2008). Once across the midline, axons increase their robo expression (but specifically down-regulate Robo3.1 in mice) and thus acquire slit sensitivity. In this way, the slit/Robo chemorepellent activity forces axons away from the midline and prevents their re-entrance. In addition, Robo seems also able to inhibit the attraction mediated by the netrin attractant receptor Dcc, possibly explaining how postcrossing axons lose their sensitivity to netrin (Stein and Tessier-Lavigne 2001; reviewed in Dickson and Gilestro 2006; Evans and Bashaw 2010; Ypsilanti et al. 2010).

Although considerable progress has been made in determining the function of netrins and slits during axonal guidance, many questions 


\section{C.S. Barros et al.}

await further investigation, such as how the different ligands and receptor subtypes precisely mediate varying effect in different contexts and in a temporal manner. In this respect, it will be crucial to further investigate the interactions of netrins and slits with additional coreceptors including other ECM molecules.

\section{SYNAPTOGENESIS AND NEURAL CIRCUIT FORMATION}

Synapses are surrounded by a protein meshwork secreted by neurons and astrocytes (Dityatev and Schachner 2006). The vertebrate neuromuscular junction (NMJ), where motoneurons contact muscle fibers (Fig. 3), has served as a model to study ECM functions at peripheral synapses. In the CNS, the ECM forms perineuronal nets (PNNs) enwrapping neuronal cell bodies and processes (Fig. 4), which affect their development and function (Celio et al. 1998).

\section{The Neuromuscular Junction}

At the NMJ, motoneuron terminals release acetylcholine (ACh), which binds ACh receptors (AChr) at postsynaptic membranes, leading to muscle contraction (Wu et al. 2010). NMJs are embedded in a specialized BL containing collagen IV, laminins, heparan sulfate proteoglycans (HSPs) and various other glycoproteins (Fig. 3) (Patton 2003).

\section{Agrin and Laminins}

Agrin is a HSP released by motoneurons into the BL. In addition, muscle fibers and Schwann cells produce distinct agrin isoforms (Werle 2008). Agrin-deficient mice lack NMJs (Gautam et al. 1996), and agrin can induce postsynapticlike membranes in denervated muscles (Gesemann et al. 1995; Jones et al. 1997). Agrin binds to low-density lipoprotein receptor-related protein 4 (Lrp4), which interacts with MuSK, a receptor tyrosine kinase that acts as a signalosome for postsynaptic NMJ development (Fig. 3) (Glass et al. 1996; Strochlic et al. 2005; Kim et al. 2008; Zhang et al. 2008; Wu et al. 2010). A short agrin form consisting of its MuSKactivating and laminin-binding domains is sufficient to restore NMJs in agrin mutant mice when expressed by muscle, suggesting that agrin function does not depend on its local deposition at synapses (Lin et al. 2008).

Agrin, other HSPs, and nidogens stabilize networks of laminin, the most prominent noncollagenous glycoprotein of the BL at the NMJ

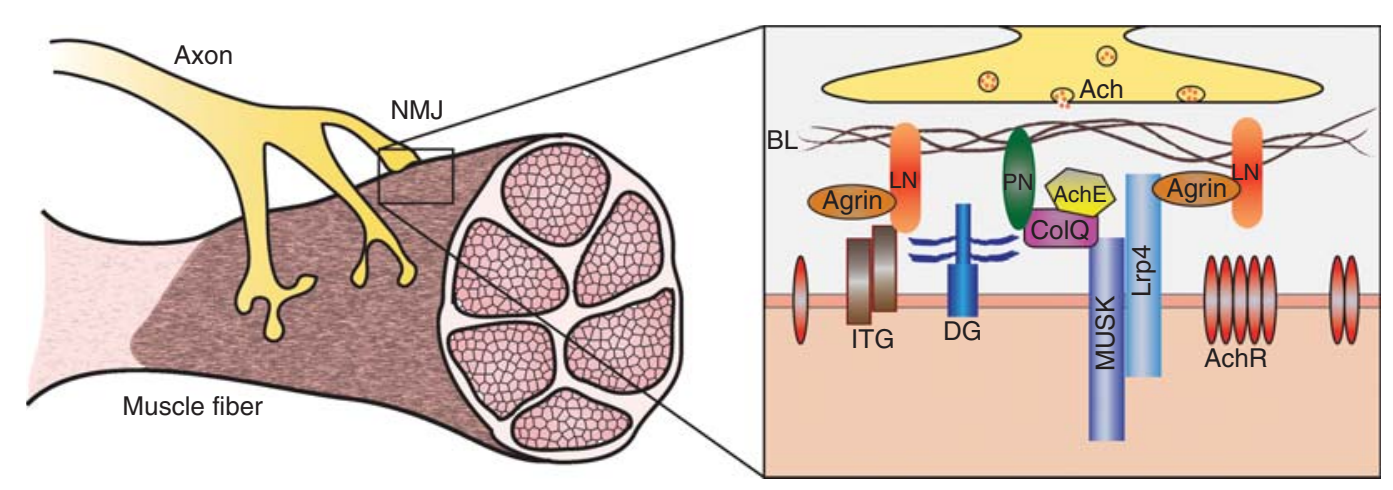

Figure 3. ECM molecules at the neuromuscular junction. ECM molecules (BL) are required for NMJ development and function. The heparan sulfate proteoglycan agrin binds to its receptor, Lrp4, and regulates postsynaptic NMJ development through the receptor tyrosine kinase, MuSK. Laminins (LN) are required at the NMJ to promote presynaptic differentiation, as well as postsynaptic maturation via integrin (ITG) and $\alpha$-dystroglycan (DG) receptors. ITG and DG receptors also bind perlecan (PN) in the BL, which recruits collagen Q (ColQ). ColQ can also bind MuSK and is important for AchR clustering and regulation of Ach levels via recruitment of acetylcholinesterase (AchE) to the NMJ. 


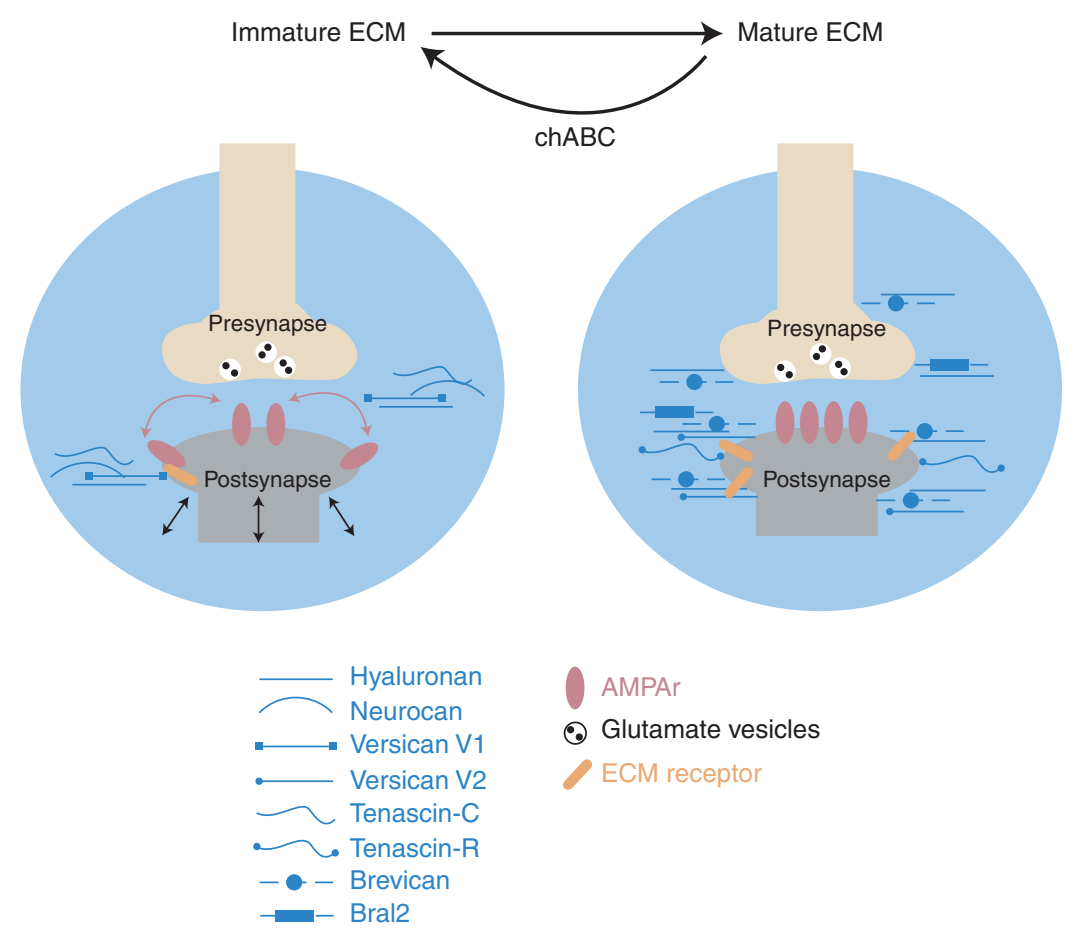

Figure 4. ECM changes at CNS synapses. Synapses are embedded into an ECM meshwork (blue) composed of hyaluronan, chondroitin sulfate proteglycans (CSPGs), tenascins, and others. The composition of the ECM changes during development. For example, neurocan, versican V1, and tenascin-C are abundant in the immature CNS, whereas tenascin-R, versican V2, and Brall are prominent in the mature CNS. The mature ECM is thought to restrict dendritic spine motility and lateral diffusion of AMPA receptors (AMPAr). Chondroitinase $\mathrm{ABC}$ (chABC) digestion of CSPGs can restore juvenile spine dynamics.

(Fig. 3) (Massoulie and Millard 2009). $\beta 2$-containing laminins bind calcium channels, inducing their clustering and consequent assembly of presynaptic proteins. Deletion of laminin $\beta 2$ results in loss of NMJ presynaptic active zones where neurotransmitters are released (Noakes et al. 1995; Knight et al. 2003; Nishimune et al. 2004; Miner et al. 2006; Fox et al. 2007). Laminin $\alpha 4$ is also required for presynaptic differentiation (Ichikawa et al. 2005) and for the correct apposition between active zones and postsynaptic sites (Patton et al. 2001). Laminins play additional roles in postsynaptic maturation. Clustering of AChr is delayed in muscles of laminin $\alpha 5$ mutant mice and arrested in $\alpha 4 / \alpha 5$ double mutants (Nishimune et al. 2008). Furthermore, agrin-induced aggregation of AChr in myotubes correlates with laminin recruitment (Montanaro et al. 1998). This laminin-mediated effect is MuSK-independent, occurring instead via the dual agrin/laminin receptor $\alpha$-dystroglycan (Montanaro et al. 1998; Nishimune et al. 2008), which plays vital roles in maturation of the NMJ and central synapses (Grady et al. 2000; Jacobson et al. 2001; Pilgram et al. 2010). Integrins are additional laminin receptors at the NMJ (Barros and Muller 2005). $\beta 1$-integrins modulate AChr clustering in cultured myotubes (Martin and Sanes 1997). In vivo, ablation of $\beta 1$-integrins in motoneurons has little effect on NMJ formation, but its loss in muscle leads to defective motoneuron-muscle interactions, resulting in excessive nerve branching and preventing normal NMJ presynaptic differentiation (Schwander et al. 2004). These defects resemble the phenotype of agrin-null mice, indicating $\beta 1$-integrins may be required for the presentation of agrin 
C.S. Barros et al.

and/or laminin to motor nerve terminals (Schwander et al. 2004).

\section{Collagens}

The most abundant BL protein at NMJs is collagen IV (Sanes 2003). Collagen IV chains $\alpha 1$ and 2 are implicated in NMJ nerve terminal maturation, while $\alpha 3 / 6$ chains are required for their maintenance (Fox et al. 2007). CollagenQ (ColQ), another collagen at the NMJ, anchors acetylcholinesterase (AChE), a serine hydrolase controlling ACh levels, to the ECM (Bon et al. 1997; Sigoillot et al. 2010b), and it is required for AChr clustering and synaptic gene expression via its interaction with MuSK (Sigoillot et al. 2010a; Sigoillot et al. 2010b). ColQ binds perlecan, which associates with dystroglycan, laminin and $\beta 1$-integrins (Talts et al. 1999; Bix et al. 2004). Perlecan also stabilizes AChE to NMJs (Peng et al. 1999; ArikawaHirasawa et al. 2002), but it is unclear if it cooperates with ColQ in this function.

\section{Central Synapses}

In the CNS, the carbohydrate hyaluronan (HA) forms the backbone of PNNs. During nervous system maturation, many ECM molecules at PNNs are replaced by others of the same family, allowing for maintenance of overall ECM structure (Rauch 2004). For example, neurocan, versican V1, and tenascin-C are abundant in the juvenile rodent $\mathrm{CNS}$, whereas brevican, versican V2, tenascin-R, Bral2, and HA synthases are prominent in the mature CNS (Bruckner et al. 2000; Bekku et al. 2003; Carulli et al. 2006; Carulli et al. 2007; Galtrey et al. 2008) (Fig. 4). Because some ECM components are inhibitory for cell adhesion and fiber outgrowth (Pesheva et al. 1989; Morganti et al. 1990; Angelov et al. 1998), the ECM has originally been thought of as inhibiting synaptogenesis, a view that has recently changed.

\section{Chondroitin Sulfate Proteoglycans}

In the model of ocular dominance plasticity, monocular deprivation leads to an ocular dominance shift in young animals that is not observed in adults. Reactivation of ocular dominance plasticity in adults can be achieved following enzymatic degradation of CSPGs (Pizzorusso et al. 2002). Brief monocular deprivation increases dendritic spine motility and occludes subsequent effects of ECM degradation, indicating that this mechanism may act to permit synapse remodeling during ocular dominance plasticity (Oray et al. 2004). Degradation of CSPGs at PNNs also renders subsequently acquired fear memories susceptible to erasure, implicating PNNs in the formation of stable memories (Gogolla et al. 2009). Finally, ECM removal restores juvenile AMPA-type neurotransmitter receptor (AMPAr) mobility in mature neurons, suggesting that PNNs compartmentalize neuronal surfaces and participate in short-term synaptic plasticity (Frischknecht et al. 2009). In sum, PNNs contribute to the formation of neural circuitry by restricting structural changes at synapses (Fig. 4), and by modulating experience-dependent synaptic plasticity. Key players are likely molecules regulating perisynaptic ECM proteolysis in an activity-dependent manner (Nakamura et al. 2000; Berardi et al. 2004; Lochner et al. 2006; Frischknecht et al. 2008; Lee et al. 2008).

\section{Reelin}

Reelin regulates not only neuronal migration but also synapse development and function (Dityatev and Schachner 2006; Rogers and Weeber 2008). In the adult neocortex, reelin is secreted by GABAergic interneurons (Alcantara et al. 1998; Sinagra et al. 2005). Reduction or loss of reelin signaling hampers arborization of hippocampal and frontal cortex neuronal dendrites, and reduces dendritic spine density (Liu et al. 2001; Niu et al. 2004; Matsuki et al. 2008; Niu et al. 2008). Conversely, transgenic mice overexpressing reelin show increased synaptic contacts and hypertrophy of hippocampal dendritic spines (Pujadas et al. 2010). Reelin signaling is also involved in synaptic plasticity; mice heterozygous for reelin or ApoER2 show impaired hippocampal long-term potentiation (LTP) (Weeber et al. 2002; Beffert et al. 2005; Chen et al. 2005; Qiu et al. 2006; Rogers and 
Weeber 2008). Reelin signals through ApoER2 to enhance LTP via a mechanism involving the activity-dependent splicing of an ApoER2 exon that encodes a domain required for reelininduced tyrosine phosphorylation of NMDAtype receptors (NMDAr) (Beffert et al. 2005; Beffert et al. 2006). Additionally, reelin participates in the recruitment, trafficking, and composition of NMDAr, contributing to the developmental switch of NMDAr subunits from NR2B to NR2A (Sinagra et al. 2005; Groc et al. 2007; Campo et al. 2009).

\section{Thrombospondins}

Astrocytes play an integral role in the development of synapses (Stevens 2008), and TSPs are key astrocyte-derived molecules regulating synaptogenesis. TSP 1 and 2 are secreted by immature astrocytes, correlating with the onset of synaptogenesis (Ullian et al. 2001; Christopherson et al. 2005). Applying TSP1 and 2 to cultured retinal ganglion cells increases the number of excitatory synapses. Conversely, TSP1/2 double KO mice show reduced cortical synapse density (Christopherson et al. 2005). TSP $1 / 2$ interact with the gabapentin receptor $\alpha 2 \gamma-1$, which can mediate their synaptogenic activity (Eroglu et al. 2009). TSP1/2 induced synapses are presynaptically active but postsynaptically silent (Christopherson et al. 2005), suggesting that other signals are required to convert these immature synapses into functional ones. TSP1 also accelerates formation of immature synapses in cultured hippocampal neurons (Xu et al. 2010). This effect depends on neuroligin1 (NL1) (Xu et al. 2010), which together with its neurexin ligands induces formation of synapses lacking AMPAr (Graf et al. 2004). TSP1 also binds to the reelin receptors ApoER2 and VLDLR (Blake et al. 2008). In addition, production of TSP-1 by astrocytes is enhanced by type IV collagen, an effect that depends on $\alpha 1 \beta 1$ integrins (Yonezawa et al. 2010). Given that type IV collagen plays important roles in presynaptic specialization at NMJs (Fox et al. 2007) and that $\beta 1$ integrins are required for hippocampal LTP (Chan et al. 2006; Huang et al. 2006), it will be interesting to examine if these molecules have coordinated functions with TSPs at central synapses.

\section{Other ECM Proteins}

Other ECM molecules have been implicated in the formation and plasticity of central synapses (Dityatev and Schachner 2006; Galtrey and Fawcett 2007; Lee et al. 2008; Faissner et al. 2010), such as neuronal pentraxins (NPs) and tenascins. The neuronal activity-regulated pentraxin (Narp) and the neuronal pentraxin NP1 are axonal-derived lectins enriched at excitatory synapses. The neuronal pentraxin receptor (NPR) associates with Narp and NP1, and its extracellular domain is released into the ECM. NP proteins contribute to synaptogenesis by clustering AMPAr (Xu et al. 2003; Bjartmar et al. 2006; Sia et al. 2007). In addition, NPR ectodomain cleavage by TACE is essential for metabotropic glutamate receptor-dependent long-term depression (LTD) (Cho et al. 2008). TN-R and TN-C have also been implicated in forms of synaptic plasticity. Although TN-C affects LTP and LTD in the CA1 hippocampal area via L-type calcium channels (Evers et al. 2002; Strekalova et al. 2002), loss of TN-R leads to elevated basal excitatory synaptic transmission and reduced perisomatic GABAergic inhibition (Bukalo et al. 2001; Bukalo et al. 2007). Therefore, ECM components affect synapse development and function in complex ways, in which different ECM molecules have specific effects that are likely mediated by distinct receptors.

\section{CONCLUDING REMARKS}

The genome of mammals encodes a vast range of different ECM glycoproteins that affect nearly all aspects of nervous system development and function. Although substantial progress has been made to define the functions of specific ECM molecules in the nervous system, many challenges remain. For example, which mechanisms control the composition and structure of ECM assemblies in different parts of the nervous system? How do these assemblies affect the activity of secreted growth factors 


\section{C.S. Barros et al.}

and morphogens, and how do cells integrate information provided by complex ECM mixtures? Finally, how does the three-dimensional ECM architecture and its mechanical properties affect cell behavior? Advances in genomics, proteomics, genetics, and systems level approaches will undoubtedly help provide answers to these questions.

\section{ACKNOWLEDGMENTS}

This work was supported by funding from the National Institutes of Health (S.J.F., NS060355; U.M., NS046456, MH078833), the Skaggs Institute for Chemical Biology (U.M.), and the Dorris Neuroscience Center (U.M).

\section{REFERENCES}

Abaskharoun M, Bellemare M, Lau E, Margolis RU. 2010. Expression of hyaluronan and the hyaluronan-binding proteoglycans neurocan, aggrecan, and versican by neural stem cells and neural cells derived from embryonic stem cells. Brain Res 1327: 6-15.

Adams JC, Tucker RP. 2000. The thrombospondin type 1 repeat (TSR) superfamily: diverse proteins with related roles in neuronal development. Dev Dyn 218: 280-299.

Alcantara S, Ruiz M, D’Arcangelo G, Ezan F, de Lecea L, Curran T, Sotelo C, Soriano E. 1998. Regional and cellular patterns of reelin mRNA expression in the forebrain of the developing and adult mouse. J Neurosci 18: 7779-7799.

Angelov DN, Walther M, Streppel M, Guntinas-Lichius O, Neiss WF, Probstmeier R, Pesheva P. 1998. Tenascin-R is antiadhesive for activated microglia that induce downregulation of the protein after peripheral nerve injury: A new role in neuronal protection. J Neurosci 18: 6218-6229.

Arikawa-Hirasawa E, Rossi SG, Rotundo RL, Yamada Y. 2002. Absence of acetylcholinesterase at the neuromuscular junctions of perlecan-null mice. Nat Neurosci 5: 119-123.

Arnaud L, Ballif BA, Forster E, Cooper JA. 2003. Fyn tyrosine kinase is a critical regulator of disabled-1 during brain development. Curr Biol 13: 9-17.

Assadi AH, Zhang G, Beffert U, McNeil RS, Renfro AL, Niu S, Quattrocchi CC, Antalffy BA, Sheldon M, Armstrong DD, et al. 2003. Interaction of reelin signaling and Lis 1 in brain development. Nat Genet 35: 270-276.

Bagri A, Marin O, Plump AS, Mak J, Pleasure SJ, Rubenstein JL, Tessier-Lavigne M. 2002. Slit proteins prevent midline crossing and determine the dorsoventral position of major axonal pathways in the mammalian forebrain. Neuron 33: 233-248.

Bai F, Peng H, Etlinger JD, Zeman RJ. 2010. Partial functional recovery after complete spinal cord transection by combined chondroitinase and clenbuterol treatment. Pflugers Arch 460: 657-666.

Ballif BA, Arnaud L, Arthur WT, Guris D, Imamoto A, Cooper JA. 2004. Activation of a Dab1/CrkL/C3G/ Rapl pathway in Reelin-stimulated neurons. Curr Biol 14: 606-610.

Bamdad M, Volle D, Dastugue B, Meiniel A. 2004. $\alpha a 1 \beta 1$-integrin is an essential signal for neurite outgrowth induced by thrombospondin type 1 repeats of SCO-spondin. Cell Tissue Res 315: 15-25.

Bandtlow CE, Zimmermann DR. 2000. Proteoglycans in the developing brain: New conceptual insights for old proteins. Physiol Rev 80: 1267-1290.

Barallobre MJ, Pascual M, Del Rio JA, Soriano E. 2005. The Netrin family of guidance factors: Emphasis on Netrin-1 signalling. Brain Res Brain Res Rev 49: 22-47.

Barros CS, Muller U. 2005. Cell adhesion in nervous system development: Integrin fuctions in glia cells. In Integrins in Development (ed. E Danen). Landes Bioscience, Georgetown, TX.

Barros CS, Nguyen T, Spencer KS, Nishiyama A, Colognato H, Muller U. 2009. Betal integrins are required for normal CNS myelination and promote AKT-dependent myelin outgrowth. Development 136: 2717-2724.

Bartsch S, Bartsch U, Dorries U, Faissner A, Weller A, Ekblom P, Schachner M. 1992. Expression of tenascin in the developing and adult cerebellar cortex. J Neurosci 12: 736-749.

Becker CG, Schweitzer J, Feldner J, Becker T, Schachner M. 2003. Tenascin-R as a repellent guidance molecule for developing optic axons in zebrafish. J Neurosci 23: 6232-6237.

Becker CG, Schweitzer J, Feldner J, Schachner M, Becker T. 2004. Tenascin-R as a repellent guidance molecule for newly growing and regenerating optic axons in adult zebrafish. Mol Cell Neurosci 26: 376-389.

Beffert U, Durudas A, Weeber EJ, Stolt PC, Giehl KM, Sweatt JD, Hammer RE, Herz J. 2006. Functional dissection of Reelin signaling by site-directed disruption of Disabled-1 adaptor binding to apolipoprotein E receptor 2: distinct roles in development and synaptic plasticity. J Neurosci 26: $2041-2052$.

Beffert U, Weeber EJ, Durudas A, Qiu S, Masiulis I, Sweatt JD, Li WP, Adelmann G, Frotscher M, Hammer RE, et al. 2005. Modulation of synaptic plasticity and memory by Reelin involves differential splicing of the lipoprotein receptor Apoer2. Neuron 47: 567-579.

Bekku Y, Rauch U, Ninomiya Y, Oohashi T. 2009. Brevican distinctively assembles extracellular components at the large diameter nodes of Ranvier in the CNS. J Neurochem 108: $1266-1276$.

Bekku Y, Su WD, Hirakawa S, Fassler R, Ohtsuka A, Kang JS, Sanders J, Murakami T, Ninomiya Y, Oohashi T. 2003. Molecular cloning of Bral2, a novel brain-specific link protein, and immunohistochemical colocalization with brevican in perineuronal nets. Mol Cell Neurosci 24: 148-159.

Bekku Y, Vargova L, Goto Y, Vorisek I, Dmytrenko L, Narasaki M, Ohtsuka A, Fassler R, Ninomiya Y, Sykova E, et al. 2010. Brall: Its role in diffusion barrier formation and conduction velocity in the CNS. J Neurosci 30: 3113-3123. 
Beltran-Valero de Bernabe D, Currier S, Steinbrecher A, Celli J, van Beusekom E, van der Zwaag B, Kayserili H, Merlini L, Chitayat D, Dobyns WB, et al. 2002. Mutations in the O-mannosyltransferase gene POMT1 give rise to the severe neuronal migration disorder Walker-Warburg syndrome. Am J Hum Genet 71: 1033-1043.

Belvindrah R, Graus-Porta D, Goebbels S, Nave KA, Muller U. 2007a. $\beta 1$ integrins in radial glia but not in migrating neurons are essential for the formation of cell layers in the cerebral cortex. J Neurosci 27: 13854-13865.

Belvindrah R, Hankel S, Walker J, Patton BL, Muller U. 2007b. $\beta 1$ integrins control the formation of cell chains in the adult rostral migratory stream. J Neurosci 27: 2704-2717.

Benhayon D, Magdaleno S, Curran T. 2003. Binding of purified Reelin to ApoER2 and VLDLR mediates tyrosine phosphorylation of Disabled-1. Brain Res Mol Brain Res 112: 33-45.

Berardi N, Pizzorusso T, Maffei L. 2004. Extracellular matrix and visual cortical plasticity: Freeing the synapse. Neuron 44: 905-908.

Bix G, Fu J, Gonzalez EM, Macro L, Barker A, Campbell S, Zutter MM, Santoro SA, Kim JK, Hook M, et al. 2004. Endorepellin causes endothelial cell disassembly of actin cytoskeleton and focal adhesions through $\alpha 2 \beta 1$ integrin. J Cell Biol 166: 97-109.

Bjartmar L, Huberman AD, Ullian EM, Renteria RC, Liu X, Xu W, Prezioso J, Susman MW, Stellwagen D, Stokes CC, et al. 2006. Neuronal pentraxins mediate synaptic refinement in the developing visual system. J Neurosci 26: 6269-6281.

Blaess S, Graus-Porta D, Belvindrah R, Radakovits R, Pons S, Littlewood-Evans A, Senften M, Guo H, Li Y, Miner JH, et al. 2004. $\beta 1$-integrins are critical for cerebellar granule cell precursor proliferation. J Neurosci 24: 3402-3412.

Blake SM, Strasser V, Andrade N, Duit S, Hofbauer R, Schneider WJ, Nimpf J. 2008. Thrombospondin-1 binds to ApoER2 and VLDL receptor and functions in postnatal neuronal migration. EMBO J 27: 3069-3080.

Bock HH, Jossin Y, Liu P, Forster E, May P, Goffinet AM, Herz J. 2003. Phosphatidylinositol 3-kinase interacts with the adaptor protein Dab1 in response to Reelin signaling and is required for normal cortical lamination. J Biol Chem 278: 38772-38779.

Bon S, Coussen F, Massoulie J. 1997. Quaternary associations of acetylcholinesterase. II. The polyproline attachment domain of the collagen tail. J Biol Chem 272: 3016-3021.

Bradbury EJ, Moon LD, Popat RJ, King VR, Bennett GS, Patel PN, Fawcett JW, McMahon SB. 2002. Chondroitinase $\mathrm{ABC}$ promotes functional recovery after spinal cord injury. Nature 416: 636-640.

Bradford D, Cole SJ, Cooper HM. 2009. Netrin-1: Diversity in development. Int J Biochem Cell Biol 41: 487-493.

Bradl M, Lassmann H. 2010. Oligodendrocytes: Biology and pathology. Acta Neuropathol 119: 37-53.

Bray GM, Perkins S, Peterson AC, Aguayo AJ. 1977. Schwann cell multiplication deficit in nerve roots of newborn dystrophic mice. A radioautographic and ultrastructural study. J Neurol Sci 32: 203-212.
Bruckner G, Grosche J, Schmidt S, Hartig W, Margolis RU, Delpech B, Seidenbecher CI, Czaniera R, Schachner M. 2000. Postnatal development of perineuronal nets in wild-type mice and in a mutant deficient in tenascin-R. J Comp Neurol 428: 616-629.

Bukalo O, Schachner M, Dityatev A. 2001. Modification of extracellular matrix by enzymatic removal of chondroitin sulfate and by lack of tenascin-R differentially affects several forms of synaptic plasticity in the hippocampus. Neurosci 104: 359-369.

Bukalo O, Schachner M, Dityatev A. 2007. Hippocampal metaplasticity induced by deficiency in the extracellular matrix glycoprotein tenascin-R. J Neurosci 27: 60196028.

Burstyn-Cohen T, Frumkin A, Xu YT, Scherer SS, Klar A. 1998. Accumulation of F-spondin in injured peripheral nerve promotes the outgrowth of sensory axons. J Neurosci 18: $8875-8885$.

Burstyn-Cohen T, Tzarfaty V, Frumkin A, Feinstein Y, Stoeckli E, Klar A. 1999. F-Spondin is required for accurate pathfinding of commissural axons at the floor plate. Neuron 23: 233-246.

Caggiano AO, Zimber MP, Ganguly A, Blight AR, Gruskin EA. 2005. Chondroitinase ABCI improves locomotion and bladder function following contusion injury of the rat spinal cord. J Neurotrauma 22: 226-239.

Calderwood DA, Fujioka Y, de Pereda JM, Garcia-Alvarez B, Nakamoto T, Margolis B, McGlade CJ, Liddington RC, Ginsberg MH. 2003. Integrin beta cytoplasmic domain interactions with phosphotyrosine-binding domains: A structural prototype for diversity in integrin signaling. Proc Natl Acad Sci 100: 2272-2277.

Calof AL, Reichardt LF. 1985. Response of purified chick motoneurons to myotube conditioned medium: Laminin is essential for the substratum-binding, neurite outgrowth-promoting activity. Neurosci Lett 59: $183-$ 189.

Campo CG, Sinagra M, Verrier D, Manzoni OJ, Chavis P. 2009. Reelin secreted by GABAergic neurons regulates glutamate receptor homeostasis. PLoS One 4: e5505.

Campos LS, Leone DP, Relvas JB, Brakebusch C, Fassler R, Suter U, ffrench-Constant C. 2004. $\beta 1$ integrins activate a MAPK signalling pathway in neural stem cells that contributes to their maintenance. Development 131: 3433-3444.

Caprile T, Osorio G, Henriquez JP, Montecinos H. 2009. Polarized expression of integrin $\beta 1$ in diencephalic roof plate during chick development, a possible receptor for SCO-spondin. Dev Dyn 238: 2494-2504.

Caro PA, Scavina M, Hoffman E, Pegoraro E, Marks HG. 1999. MR imaging findings in children with merosindeficient congenital muscular dystrophy. AJNR Am J Neuroradiol 20: 324-326.

Carulli D, Rhodes KE, Fawcett JW. 2007. Upregulation of aggrecan, link protein 1 , and hyaluronan synthases during formation of perineuronal nets in the rat cerebellum. J Comp Neurol 501: 83-94.

Carulli D, Rhodes KE, Brown DJ, Bonnert TP, Pollack SJ, Oliver K, Strata P, Fawcett JW. 2006. Composition of perineuronal nets in the adult rat cerebellum and the cellular origin of their components. J Comp Neurol 494: 559-577. 


\section{C.S. Barros et al.}

Caviness VS Jr, 1973. Time of neuron origin in the hippocampus and dentate gyrus of normal and reeler mutant mice: an autoradiographic analysis. J Comp Neurol 151: 113-120.

Caviness VS Jr, 1982. Neocortical histogenesis in normal and reeler mice: A developmental study based upon $[3 \mathrm{H}]$ thymidine autoradiography. Brain Res 256: 293-302.

Caviness VS Jr, Korde MG. 1981. Monoaminergic afferents to the neocortex: a developmental histofluorescence study in normal and Reeler mouse embryos. Brain Res 209: 1-9.

Celio MR, Spreafico R, De Biasi S, Vitellaro-Zuccarello L. 1998. Perineuronal nets: Past and present. Trends Neurosci 21: $510-515$.

Chan CS, Weeber EJ, Zong L, Fuchs E, Sweatt JD, Davis RL. 2006. $\beta \beta 1$-integrins are required for hippocampal AMPA receptor-dependent synaptic transmission, synaptic plasticity, and working memory. J Neurosci 26: 223-232.

Chan SS, Zheng H, Su MW, Wilk R, Killeen MT, Hedgecock EM, Culotti JG. 1996. UNC-40, a C. elegans homolog of DCC (Deleted in Colorectal Cancer), is required in motile cells responding to UNC-6 netrin cues. Cell 87: 187-195.

Chen ZF, Paquette AJ, Anderson DJ. 1998. NRSF/REST is required in vivo for repression of multiple neuronal target genes during embryogenesis. Nat Genet 20: 136-142.

Chen Y, Beffert U, Ertunc M, Tang TS, Kavalali ET, Bezprozvanny I, Herz J. 2005. Reelin modulates NMDA receptor activity in cortical neurons. J Neurosci 25: 8209-8216.

Chen Z, Gore BB, Long H, Ma L, Tessier-Lavigne M. 2008. Alternative splicing of the Robo3 axon guidance receptor governs the midline switch from attraction to repulsion. Neuron 58: 325-332.

Chen ZL, Haegeli V, Yu H, Strickland S. 2009. Cortical deficiency of laminin gammal impairs the AKT/GSK-3 $\beta$ signaling pathway and leads to defects in neurite outgrowth and neuronal migration. Dev Biol 327: 158-168.

Chen K, Ochalski PG, Tran TS, Sahir N, Schubert M, Pramatarova A, Howell BW. 2004. Interaction between Dab1 and CrkII is promoted by Reelin signaling. $J$ Cell Sci 117: 4527-4536.

Chernousov MA, Yu WM, Chen ZL, Carey DJ, Strickland S. 2008. Regulation of Schwann cell function by the extracellular matrix. Glia 56: 1498-1507.

Cho RW, Park JM, Wolff SB, Xu D, Hopf C, Kim JA, Reddy RC, Petralia RS, Perin MS, Linden DJ, et al. 2008. mGluR1/5-dependent long-term depression requires the regulated ectodomain cleavage of neuronal pentraxin NPR by TACE. Neuron 57: 858-871.

Christopherson KS, Ullian EM, Stokes CC, Mullowney CE, Hell JW, Agah A, Lawler J, Mosher DF, Bornstein P, Barres BA. 2005. Thrombospondins are astrocytesecreted proteins that promote CNS synaptogenesis. Cell 120: 421-433.

Chun SJ, Rasband MN, Sidman RL, Habib AA, Vartanian T. 2003. Integrin-linked kinase is required for laminin2-induced oligodendrocyte cell spreading and CNS myelination. J Cell Biol 163: 397-408.
Cirulli V, Yebra M. 2007. Netrins: Beyond the brain. Nat Rev Mol Cell Biol 8: 296-306.

Colognato H, ffrench-Constant C, Feltri ML. 2005. Human diseases reveal novel roles for neural laminins. Trends Neurosci 28: $480-486$.

Colognato H, Baron W, Avellana-Adalid V, Relvas JB, BaronVan Evercooren A, Georges-Labouesse E, ffrenchConstant C. 2002. CNS integrins switch growth factor signalling to promote target-dependent survival. Nat Cell Biol 4: 833-841.

Colognato H, Ramachandrappa S, Olsen IM, ffrenchConstant C. 2004. Integrins direct Src family kinases to regulate distinct phases of oligodendrocyte development. J Cell Biol 167: 365-375.

Cooper JA. 2008. A mechanism for inside-out lamination in the neocortex. Trends Neurosci 31: 113-119.

Czopka T, Von Holst A, Schmidt G, Ffrench-Constant C, Faissner A. 2009. Tenascin C and tenascin R similarly prevent the formation of myelin membranes in a RhoAdependent manner, but antagonistically regulate the expression of myelin basic protein via a separate pathway. Glia 57: 1790-1801.

D'Arcangelo G, Homayouni R, Keshvara L, Rice DS, Sheldon M, Curran T. 1999. Reelin is a ligand for lipoprotein receptors. Neuron 24: 471-479.

De Arcangelis A, Mark M, Kreidberg J, Sorokin L, Georges-Labouesse E. 1999. Synergistic activities of $\alpha 3$ and $\alpha 6$ integrins are required during apical ectodermal ridge formation and organogenesis in the mouse. Development 126: 3957-3968.

Debby-Brafman A, Burstyn-Cohen T, Klar A, Kalcheim C. 1999. F-Spondin, expressed in somite regions avoided by neural crest cells, mediates inhibition of distinct somite domains to neural crest migration. Neuron 22: 475-488.

DeFreitas MF, Yoshida CK, Frazier WA, Mendrick DL, Kypta RM, Reichardt LF. 1995. Identification of integrin $\alpha 3 \beta 1$ as a neuronal thrombospondin receptor mediating neurite outgrowth. Neuron 15: 333-343.

Di Muzio A, De Angelis MV, Di Fulvio P, Ratti A, Pizzuti A Stuppia L, Gambi D, Uncini A. 2003. Dysmyelinating sensory-motor neuropathy in merosin-deficient congenital muscular dystrophy. Muscle Nerve 27: 500-506.

Dickson BJ, Gilestro GF. 2006. Regulation of commissural axon pathfinding by slit and its Robo receptors. Annu Rev Cell Dev Biol 22: 651-675.

Dityatev A, Schachner M. 2006. The extracellular matrix and synapses. Cell Tissue Res 326: 647-654.

Dours-Zimmermann MT, Maurer K, Rauch U, Stoffel W, Fassler R, Zimmermann DR. 2009. Versican V2 assembles the extracellular matrix surrounding the nodes of ranvier in the CNS. J Neurosci 29: 7731-7742.

Drago J, Nurcombe V, Bartlett PF. 1991. Laminin through its long arm E8 fragment promotes the proliferation and differentiation of murine neuroepithelial cells in vitro. Exp Cell Res 192: 256-265.

Dulabon L, Olson EC, Taglienti MG, Eisenhuth S, McGrath B, Walsh CA, Kreidberg JA, Anton ES. 2000. Reelin binds alpha3betal integrin and inhibits neuronal migration. Neuron 27: 33-44. 
Erickson AC, Couchman JR. 2000. Still more complexity in mammalian basement membranes. J Histochem Cytochem 48: 1291-1306.

Eroglu C, Allen NJ, Susman MW, O’Rourke NA, Park CY, Ozkan E, Chakraborty C, Mulinyawe SB, Annis DS, Huberman AD, et al. 2009. Gabapentin receptor $\alpha 2 \delta-1$ is a neuronal thrombospondin receptor responsible for excitatory CNS synaptogenesis. Cell 139: 380-392.

Esch T, Lemmon V, Banker G. 1999. Local presentation of substrate molecules directs axon specification by cultured hippocampal neurons. J Neurosci 19: 6417-6426.

Evans TA, Bashaw GJ. 2010. Axon guidance at the midline: Of mice and flies. Curr Opin Neurobiol 20: 79-85.

Evers MR, Salmen B, Bukalo O, Rollenhagen A, Bosl MR, Morellini F, Bartsch U, Dityatev A, Schachner M. 2002. Impairment of L-type $\mathrm{Ca} 2+$ channel-dependent forms of hippocampal synaptic plasticity in mice deficient in the extracellular matrix glycoprotein tenascin-C. J Neurosci 22: 7177-7194.

Faissner A, Kruse J. 1990. J1/tenascin is a repulsive substrate for central nervous system neurons. Neuron 5: 627-637.

Faissner A, Pyka M, Geissler M, Sobik T, Frischknecht R, Gundelfinger ED, Seidenbecher C. 2010. Contributions of astrocytes to synapse formation and maturationPotential functions of the perisynaptic extracellular matrix. Brain Res Rev 63: 26-38.

Feltri ML, Wrabetz L. 2005. Laminins and their receptors in Schwann cells and hereditary neuropathies. J Peripher Nerv Syst 10: $128-143$.

Feltri ML, Graus-Porta D, Previtali SC, Nodari A, Migliavacca B, Cassetti A, Littlewood-Evans A, Reichardt LF Messing A, Quattrini A, et al. 2002. Conditional disruption of $\beta 1$ integrin in Schwann cells impedes interactions with axons. J Cell Biol 156: 199-209.

Fishell G, Kriegstein AR. 2003. Neurons from radial glia: The consequences of asymmetric inheritance. Curr Opin Neurobiol 13: 34-41.

Flanagan LA, Rebaza LM, Derzic S, Schwartz PH, Monuki ES. 2006. Regulation of human neural precursor cells by laminin and integrins. J Neurosci Res 83: 845-856.

Forster E, Bock HH, Herz J, Chai X, Frotscher M, Zhao S. 2010. Emerging topics in Reelin function. Eur J Neurosci 31: 1511-1518.

Fox MA, Sanes JR, Borza DB, Eswarakumar VP, Fassler R, Hudson BG, John SW, Ninomiya Y, Pedchenko V, Pfaff SL, et al. 2007. Distinct target-derived signals organize formation, maturation, and maintenance of motor nerve terminals. Cell 129: 179-193.

Frischknecht R, Fejtova A, Viesti M, Stephan A, Sonderegger P. 2008. Activity-induced synaptic capture and exocytosis of the neuronal serine protease neurotrypsin. J Neurosci 28: $1568-1579$.

Frischknecht R, Heine M, Perrais D, Seidenbecher CI, Choquet D, Gundelfinger ED. 2009. Brain extracellular matrix affects AMPA receptor lateral mobility and shortterm synaptic plasticity. Nat Neurosci 12: 897-904.

Fujisawa K, Wrana JL, Culotti JG. 2007. The slit receptor EVA-1 coactivates a SAX-3/Robo mediated guidance signal in C. elegans. Science 317: 1934-1938.

Fuss B, Wintergerst ES, Bartsch U, Schachner M. 1993. Molecular characterization and in situ mRNA localization of the neural recognition molecule J1160/180: A modular structure similar to tenascin. J Cell Biol 120: 1237-1249.

Galtrey CM, Fawcett JW. 2007. The role of chondroitin sulfate proteoglycans in regeneration and plasticity in the central nervous system. Brain Res Rev 54: 1-18.

Galtrey CM, Kwok JC, Carulli D, Rhodes KE, Fawcett JW. 2008. Distribution and synthesis of extracellular matrix proteoglycans, hyaluronan, link proteins and tenascin- $\mathrm{R}$ in the rat spinal cord. Eur J Neurosci 27: 1373-1390.

Garcia-Alonso L, Fetter RD, Goodman CS. 1996. Genetic analysis of Laminin A in Drosophila: Extracellular matrix containing laminin A is required for ocellar axon pathfinding. Development 122: 2611-2621.

Garcion E, Faissner A, ffrench-Constant C. 2001. Knockout mice reveal a contribution of the extracellular matrix molecule tenascin- $\mathrm{C}$ to neural precursor proliferation and migration. Development 128: 2485-2496.

Garcion E, Halilagic A, Faissner A, ffrench-Constant C. 2004. Generation of an environmental niche for neural stem cell development by the extracellular matrix molecule tenascin C. Development 131: 3423-3432.

Garwood J, Garcion E, Dobbertin A, Heck N, Calco V, ffrench-Constant C, Faissner A. 2004. The extracellular matrix glycoprotein Tenascin-C is expressed by oligodendrocyte precursor cells and required for the regulation of maturation rate, survival and responsiveness to plateletderived growth factor. Eur J Neurosci 20: 2524-2540.

Gautam M, Noakes PG, Moscoso L, Rupp F, Scheller RH, Merlie JP, Sanes JR. 1996. Defective neuromuscular synaptogenesis in agrin-deficient mutant mice. Cell 85: 525-535.

Georges-Labouesse E, Mark M, Messaddeq N, Gansmuller A. 1998. Essential role of alpha 6 integrins in cortical and retinal lamination. Curr Biol 8: 983-986.

Gesemann M, Denzer AJ, Ruegg MA. 1995. Acetylcholine receptor-aggregating activity of agrin isoforms and mapping of the active site. J Cell Biol 128: 625-636.

Gilmore EC, Herrup K. 2000. Cortical development: Receiving reelin. Curr Biol 10: R162-166.

Giros A, Morante J, Gil-Sanz C, Fairen A, Costell M. 2007. Perlecan controls neurogenesis in the developing telencephalon. BMC Dev Biol 7: 29-46.

Glass DJ, Bowen DC, Stitt TN, Radziejewski C, Bruno J, Ryan TE, Gies DR, Shah S, Mattsson K, Burden SJ, et al. 1996. Agrin acts via a MuSK receptor complex. Cell 85: 513-523.

Gobron S, Monnerie H, Meiniel R, Creveaux I, Lehmann W, Lamalle D, Dastugue B, Meiniel A. 1996. SCO-spondin: A new member of the thrombospondin family secreted by the subcommissural organ is a candidate in the modulation of neuronal aggregation. J Cell Sci 109: 1053-1061.

Goffinet AM. 1983. The embryonic development of the cerebellum in normal and reeler mutant mice. Anat Embryol (Berl) 168: 73-86.

Goffinet AM, So KF, Yamamoto M, Edwards M, Caviness VS Jr, 1984. Architectonic and hodological organization of the cerebellum in reeler mutant mice. Brain Res 318: $263-276$. 


\section{C.S. Barros et al.}

Gogolla N, Caroni P, Luthi A, Herry C. 2009. Perineuronal nets protect fear memories from erasure. Science 325: $1258-1261$.

Gomez TM, Letourneau PC. 1994. Filopodia initiate choices made by sensory neuron growth cones at laminin/fibronectin borders in vitro. J Neurosci 14: 5959-5972.

Goncalves-Mendes N, Simon-Chazottes D, Creveaux I, Meiniel A, Guenet JL, Meiniel R. 2003. Mouse SCOspondin, a gene of the thrombospondin type 1 repeat (TSR) superfamily expressed in the brain. Gene 312: 263-270.

Grady RM, Zhou H, Cunningham JM, Henry MD, Campbell KP, Sanes JR. 2000. Maturation and maintenance of the neuromuscular synapse: Genetic evidence for roles of the dystrophin-glycoprotein complex. Neuron 25: 279-293.

Graf ER, Zhang X, Jin SX, Linhoff MW, Craig AM. 2004. Neurexins induce differentiation of GABA and glutamate postsynaptic specializations via neuroligins. Cell 119: 1013-1026.

Graus-Porta D, Blaess S, Senften M, Littlewood-Evans A, Damsky C, Huang Z, Orban P, Klein R, Schittny JC, Muller U. 2001. $\beta 1$-class integrins regulate the development of laminae and folia in the cerebral and cerebellar cortex. Neuron 31: 367-379.

Grewal PK, Holzfeind PJ, Bittner RE, Hewitt JE. 2001. Mutant glycosyltransferase and altered glycosylation of alpha-dystroglycan in the myodystrophy mouse. Nat Genet 28: 151-154.

Groc L, Choquet D, Stephenson FA, Verrier D, Manzoni OJ, Chavis P. 2007. NMDA receptor surface trafficking and synaptic subunit composition are developmentally regulated by the extracellular matrix protein Reelin. J Neurosci 27: 10165-10175.

Gu WL, Fu SL, Wang YX, Li Y, Lu HZ, Xu XM, Lu PH. 2009. Chondroitin sulfate proteoglycans regulate the growth, differentiation and migration of multipotent neural precursor cells through the integrin signaling pathway. $B M C$ Neurosci 10: 128-142.

Gu WL, Fu SL, Wang YX, Li Y, Wang XF, Xu XM, Lu PH. 2007. Expression and regulation of versican in neural precursor cells and their lineages. Acta Pharmacol Sin 28: 1519-1530.

Hack I, Hellwig S, Junghans D, Brunne B, Bock HH, Zhao S, Frotscher M. 2007. Divergent roles of ApoER2 and Vldlr in the migration of cortical neurons. Development 134: 3883-3891.

Halfter W, Dong S, Yip YP, Willem M, Mayer U. 2002. A critical function of the pial basement membrane in cortical histogenesis. J Neurosci 22: 6029-6040.

Hall PE, Lathia JD, Caldwell MA, Ffrench-Constant C. 2008 Laminin enhances the growth of human neural stem cells in defined culture media. BMC Neurosci 9: 71-81.

Hall DE, Neugebauer KM, Reichardt LF. 1987. Embryonic neural retinal cell response to extracellular matrix proteins: developmental changes and effects of the cell substratum attachment antibody (CSAT). J Cell Biol 104: $623-634$.

Hammond VE, So E, Cate HS, Britto JM, Gunnersen JM, Tan SS. 2010. Cortical layer development and orientation is modulated by relative contributions of Reelin-negative and -positive neurons in mouse chimeras. Cereb Cortex 20: 2017-2026.

Hartmann U, Maurer P. 2001. Proteoglycans in the nervous system - the quest for functional roles in vivo. Matrix Biol 20: $23-35$.

Hashimoto-Torii K, Torii M, Sarkisian MR, Bartley CM, Shen J, Radtke F, Gridley T, Sestan N, Rakic P. 2008. Interaction between Reelin and Notch signaling regulates neuronal migration in the cerebral cortex. Neuron 60: 273-284.

Haubst N, Georges-Labouesse E, De Arcangelis A, Mayer U, Gotz M. 2006. Basement membrane attachment is dispensable for radial glial cell fate and for proliferation, but affects positioning of neuronal subtypes. Development 133: 3245-3254.

Hedgecock EM, Culotti JG, Hall DH. 1990. The unc-5, unc- 6 , and unc- 40 genes guide circumferential migrations of pioneer axons and mesodermal cells on the epidermis in C. elegans. Neuron 4: 61-85.

Helbling-Leclerc A, Zhang X, Topaloglu H, Cruaud C, Tesson F, Weissenbach J, Tome FM, Schwartz K, Fardeau M, Tryggvason K, et al. 1995. Mutations in the laminin $\alpha 2$-chain gene (LAMA2) cause merosin-deficient congenital muscular dystrophy. Nat Genet 11: 216-218.

Hoffarth RM, Johnston JG, Krushel LA, van der Kooy D. 1995. The mouse mutation reeler causes increased adhesion within a subpopulation of early postmitotic cortical neurons. J Neurosci 15: 4838-4850.

Hoffman JR, O'Shea KS. 1999a. Thrombospondin expression in nerve regeneration I. Comparison of sciatic nerve crush, transection, and long-term denervation. Brain Res Bull 48: 413-420.

Hoffman JR, O'Shea KS. 1999b. Thrombospondin expression in nerve regeneration II. Comparison of optic nerve crush in the mouse and goldfish. Brain Res Bull 48: 421-427.

Hong K, Hinck L, Nishiyama M, Poo MM, Tessier-Lavigne M, Stein E. 1999. A ligand-gated association between cytoplasmic domains of UNC5 and DCC family receptors converts netrin-induced growth cone attraction to repulsion [see comments]. Cell 97: 927-941.

Hong SE, Shugart YY, Huang DT, Shahwan SA, Grant PE, Hourihane JO, Martin ND, Walsh CA. 2000. Autosomal recessive lissencephaly with cerebellar hypoplasia is associated with human RELN mutations. Nat Genet 26: 93-96.

Hopker VH, Shewan D, Tessier-Lavigne M, Poo M, Holt C. 1999. Growth-cone attraction to netrin-1 is converted to repulsion by laminin-1. Nature 401: 69-73.

Howell BW, Herrick TM, Cooper JA. 1999. Reelin-induced tyrosine [corrected] phosphorylation of disabled 1 during neuronal positioning. Genes Dev 13: 643-648.

Hoyo-Becerra C, Lopez-Avalos MD, Cifuentes M, Visser R, Fernandez-Llebrez P, Grondona JM. 2010. The subcommissural organ and the development of the posterior commissure in chick embryos. Cell Tissue Res 339: 383-395.

Hu H. 2001. Cell-surface heparan sulfate is involved in the repulsive guidance activities of Slit 2 protein. Nat Neurosci 4: 695-701. 
Huang Y, Magdaleno S, Hopkins R, Slaughter C, Curran T, Keshvara L. 2004. Tyrosine phosphorylated Disabled 1 recruits Crk family adapter proteins. Biochem Biophys Res Commun 318: 204-212.

Huang Z, Shimazu K, Woo NH, Zang K, Muller U, Lu B, Reichardt LF. 2006. Distinct roles of the $\beta 1$-class integrins at the developing and the mature hippocampal excitatory synapse. J Neurosci 26: 11208-11219.

Huang W, Zhang L, Niu R, Liao H. 2009. Tenascin-R distinct domains modulate migration of neural stem/progenitor cells in vitro. In Vitro Cell Dev Biol Anim 45: 10-14.

Ichikawa N, Kasai S, Suzuki N, Nishi N, Oishi S, Fujii N, Kadoya Y, Hatori K, Mizuno Y, Nomizu M, et al. 2005. Identification of neurite outgrowth active sites on the laminin $\alpha 4$ chain $\mathrm{G}$ domain. Biochemistry 44: 57555762.

Itoh A, Miyabayashi T, Ohno M, Sakano S. 1998. Cloning and expressions of three mammalian homologues of Drosophila slit suggest possible roles for Slit in the formation and maintenance of the nervous system. Brain Res Mol Brain Res 62: 175-186.

Jacobson C, Cote PD, Rossi SG, Rotundo RL, Carbonetto S. 2001. The dystroglycan complex is necessary for stabilization of acetylcholine receptor clusters at neuromuscular junctions and formation of the synaptic basement membrane. J Cell Biol 152: 435-450.

Jankovski A, Sotelo C. 1996. Subventricular zone-olfactory bulb migratory pathway in the adult mouse: Cellular composition and specificity as determined by heterochronic and heterotopic transplantation. J Comp Neurol 371: 376-396.

Jones G, Meier T, Lichtsteiner M, Witzemann V, Sakmann B, Brenner HR. 1997. Induction by agrin of ectopic and functional postsynaptic-like membrane in innervated muscle. Proc Natl Acad Sci 94: 2654-2659.

Jossin Y, Ignatova N, Hiesberger T, Herz J, Lambert de Rouvroit C, Goffinet AM. 2004. The central fragment of Reelin, generated by proteolytic processing in vivo, is critical to its function during cortical plate development. J Neurosci 24: 514-521.

Kearns SM, Laywell ED, Kukekov VK, Steindler DA. 2003. Extracellular matrix effects on neurosphere cell motility. Exp Neurol 182: 240-244.

Keino-Masu K, Masu M, Hinck L, Leonardo ED, Chan SS, Culotti JG, Tessier-Lavigne M. 1996. Deleted in Colorectal Cancer (DCC) encodes a netrin receptor. Cell 87: 175-185.

Keleman K, Dickson BJ. 2001. Short- and long-range repulsion by the Drosophila Unc5 netrin receptor. Neuron 32: 605-617.

Keleman K, Ribeiro C, Dickson BJ. 2005. Comm function in commissural axon guidance: cell-autonomous sorting of Robo in vivo. Nat Neurosci 8: 156-163.

Keleman K, Rajagopalan S, Cleppien D, Teis D, Paiha K, Huber LA, Technau GM, Dickson BJ. 2002. Comm sorts robo to control axon guidance at the Drosophila midline. Cell 110: 415-427.

Kidd T, Bland KS, Goodman CS. 1999. Slit is the midline repellent for the robo receptor in Drosophila. Cell 96: $785-794$.
Kiernan BW, Garcion E, Ferguson J, Frost EE, Torres EM, Dunnett SB, Saga Y, Aizawa S, Faissner A, Kaur R, et al. 1999. Myelination and behaviour of tenascin-C null transgenic mice. Eur J Neurosci 11: 3082-3092.

Killeen MT, Sybingco SS. 2008. Netrin, Slit and Wnt receptors allow axons to choose the axis of migration. Dev Biol 323: $143-151$.

Kim N, Stiegler AL, Cameron TO, Hallock PT, Gomez AM, Huang JH, Hubbard SR, Dustin ML, Burden SJ. 2008. Lrp4 is a receptor for Agrin and forms a complex with MuSK. Cell 135: 334-342.

Klar A, Baldassare M, Jessell TM. 1992. F-spondin: a gene expressed at high levels in the floor plate encodes a secreted protein that promotes neural cell adhesion and neurite extension. Cell 69: 95-110.

Knight D, Tolley LK, Kim DK, Lavidis NA, Noakes PG. 2003. Functional analysis of neurotransmission at $\beta 2$-laminin deficient terminals. J Physiol 546: 789-800.

Kokovay E, Shen Q, Temple S. 2008. The incredible elastic brain: How neural stem cells expand our minds. Neuron 60: 420-429.

Kolodziej PA, Timpe LC, Mitchell KJ, Fried SR, Goodman CS, Jan LY, Jan YN. 1996. frazzled encodes a Drosophila member of the DCC immunoglobulin subfamily and is required for CNS and motor axon guidance. Cell 87: 197-204.

Kriegstein AR, Noctor SC. 2004. Patterns of neuronal migration in the embryonic cortex. Trends Neurosci 27: $392-$ 399.

Lander AD, Fujii DK, Reichardt LF. 1985a. Laminin is associated with the "neurite outgrowth-promoting factors" found in conditioned media. Proc Natl Acad Sci 82: 2183-2187.

Lander AD, Fujii DK, Reichardt LF. 1985b. Purification of a factor that promotes neurite outgrowth: Isolation of laminin and associated molecules. J Cell Biol 101: 898-913.

Lathia JD, Patton B, Eckley DM, Magnus T, Mughal MR, Sasaki T, Caldwell MA, Rao MS, Mattson MP, ffrenchConstant C. 2007. Patterns of laminins and integrins in the embryonic ventricular zone of the CNS. J Comp Neurol 505: 630-643.

Lee TW, Tsang VW, Birch NP. 2008. Synaptic plasticityassociated proteases and protease inhibitors in the brain linked to the processing of extracellular matrix and cell adhesion molecules. Neuron Glia Biol 4: 223-234.

Leite CC, Lucato LT, Martin MG, Ferreira LG, Resende MB, Carvalho MS, Marie SK, Jinkins JR, Reed UC. 2005. Merosin-deficient congenital muscular dystrophy (CMD): A study of 25 Brazilian patients using MRI. Pediatr Radiol 35: $572-579$.

Liao H, Huang W, Schachner M, Guan Y, Guo J, Yan J, Qin J, Bai X, Zhang L. 2008. $\beta 1$ integrin-mediated effects of tenascin-R domains EGFL and FN6-8 on neural stem/ progenitor cell proliferation and differentiation in vitro. J Biol Chem 283: 27927-27936.

Liesi P. 1992. Neuronal migration on laminin involves neuronal contact formation followed by nuclear movement inside a preformed process. Exp Neurol 117: 103-113.

Liesi P, Seppala I, Trenkner E. 1992. Neuronal migration in cerebellar microcultures is inhibited by antibodies 


\section{C.S. Barros et al.}

against a neurite outgrowth domain of laminin. J Neurosci Res 33: 170-176.

Lillien L, Raphael H. 2000. BMP and FGF regulate the development of EGF-responsive neural progenitor cells. Development 127: 4993-5005.

Lin S, Maj M, Bezakova G, Magyar JP, Brenner HR, Ruegg MA. 2008. Muscle-wide secretion of a miniaturized form of neural agrin rescues focal neuromuscular innervation in agrin mutant mice. Proc Natl Acad Sci 105: 11406-11411.

Liu WS, Pesold C, Rodriguez MA, Carboni G, Auta J, Lacor P, Larson J, Condie BG, Guidotti A, Costa E. 2001. Downregulation of dendritic spine and glutamic acid decarboxylase 67 expressions in the reelin haploinsufficient heterozygous reeler mouse. Proc Natl Acad Sci 98: 3477-3482.

Lochner JE, Honigman LS, Grant WF, Gessford SK, Hansen AB, Silverman MA, Scalettar BA. 2006. Activity-dependent release of tissue plasminogen activator from the dendritic spines of hippocampal neurons revealed by live-cell imaging. J Neurobiol 66: 564-577.

Lochter A, Taylor J, Fuss B, Schachner M. 1994. The extracellular matrix molecule janusin regulates neuronal morphology in a substrate- and culture time-dependent manner. Eur J Neurosci 6: 597-606.

Loulier K, Lathia JD, Marthiens V, Relucio J, Mughal MR, Tang SC, Coksaygan T, Hall PE, Chigurupati S, Patton B, et al. 2009. $\beta 1$ integrin maintains integrity of the embryonic neocortical stem cell niche. PLoS Biol 7: e1000176.

Luckenbill-Edds L. 1997. Laminin and the mechanism of neuronal outgrowth. Brain Res Brain Res Rev 23: 1-27.

Luque JM, Morante-Oria J, Fairen A. 2003. Localization of ApoER2, VLDLR and Dab1 in radial glia: Groundwork for a new model of reelin action during cortical development. Brain Res Dev Brain Res 140: 195-203.

Ly A, Nikolaev A, Suresh G, Zheng Y, Tessier-Lavigne M, Stein E. 2008. DSCAM is a netrin receptor that collaborates with DCC in mediating turning responses to netrin-1. Cell 133: 1241-1254.

Ma W, Tavakoli T, Derby E, Serebryakova Y, Rao MS, Mattson MP. 2008. Cell-extracellular matrix interactions regulate neural differentiation of human embryonic stem cells. BMC Dev Biol 8: 90-103.

Malatesta P, Appolloni I, Calzolari F. 2008. Radial glia and neural stem cells. Cell Tissue Res 331: 165-178.

Marchetti G, Escuin S, van der Flier A, De Arcangelis A, Hynes RO, Georges-Labouesse E. 2010. Integrin $\alpha 5 \beta 1$ is necessary for regulation of radial migration of cortical neurons during mouse brain development. Eur J Neurosci 31: 399-409.

Mariani J, Crepel F, Mikoshiba K, Changeux JP, Sotelo C. 1977. Anatomical, physiological and biochemical studies of the cerebellum from Reeler mutant mouse. Philos Trans R Soc Lond B Biol Sci 281: 1-28.

Martin PT, Sanes JR. 1997. Integrins mediate adhesion to agrin and modulate agrin signaling. Development 124: 3909-3917.

Massoulie J, Millard CB. 2009. Cholinesterases and the basal lamina at vertebrate neuromuscular junctions. Curr Opin Pharmacol 9: 316-325.
Matsuki T, Pramatarova A, Howell BW. 2008. Reduction of Crk and CrkL expression blocks reelin-induced dendritogenesis. J Cell Sci 121: 1869-1875.

McKeon RJ, Hoke A, Silver J. 1995. Injury-induced proteoglycans inhibit the potential for laminin-mediated axon growth on astrocytic scars. Exp Neurol 136: 32-43.

Meiniel O, Meiniel R, Lalloue F, Didier R, Jauberteau MO, Meiniel A, Petit D. 2008. The lengthening of a giant protein: When, how, and why? J Mol Evol 66: 1-10.

Melendez-Vasquez C, Carey DJ, Zanazzi G, Reizes O, Maurel P, Salzer JL. 2005. Differential expression of proteoglycans at central and peripheral nodes of Ranvier. Glia 52: 301-308.

Menager C, Arimura N, Fukata Y, Kaibuchi K. 2004. PIP3 is involved in neuronal polarization and axon formation. $J$ Neurochem 89: 109-118.

Mercado ML, Nur-e-Kamal A, Liu HY, Gross SR, Movahed R, Meiners S. 2004. Neurite outgrowth by the alternatively spliced region of human tenascin- $\mathrm{C}$ is mediated by neuronal $\alpha 7 \beta 1$ integrin. J Neurosci 24: 238-247.

Michele DE, Barresi R, Kanagawa M, Saito F, Cohn RD, Satz JS, Dollar J, Nishino I, Kelley RI, Somer H, et al. 2002. Post-translational disruption of dystroglycan-ligand interactions in congenital muscular dystrophies. Nature 418: $417-422$.

Miller FD, Gauthier-Fisher A. 2009. Home at last: neural stem cell niches defined. Cell Stem Cell 4: 507-510.

Milner R, Campbell IL. 2002. The integrin family of cell adhesion molecules has multiple functions within the CNS. J Neurosci Res 69: 286-291.

Miner JH, Go G, Cunningham J, Patton BL, Jarad G. 2006. Transgenic isolation of skeletal muscle and kidney defects in laminin $\beta 2$ mutant mice: Implications for Pierson syndrome. Development 133: 967-975.

Mobley AK, Tchaicha JH, Shin J, Hossain MG, McCarty JH. 2009. $\beta 8$ integrin regulates neurogenesis and neurovascular homeostasis in the adult brain. J Cell Sci 122: 1842-1851.

Moller JC, Klein MA, Haas S, Jones LL, Kreutzberg GW, Raivich G. 1996. Regulation of thrombospondin in the regenerating mouse facial motor nucleus. Glia 17: 121- 132 .

Montanaro F, Gee SH, Jacobson C, Lindenbaum MH, Froehner SC, Carbonetto S. 1998. Laminin and $\alpha$-dystroglycan mediate acetylcholine receptor aggregation via a MuSK-independent pathway. J Neurosci 18: 1250-1260.

Moon LD, Asher RA, Rhodes KE, Fawcett JW. 2001. Regeneration of CNS axons back to their target following treatment of adult rat brain with chondroitinase ABC. Nat Neurosci 4: 465-466.

Moore SA, Saito F, Chen J, Michele DE, Henry MD, Messing A, Cohn RD, Ross-Barta SE, Westra S, Williamson RA, et al. 2002. Deletion of brain dystroglycan recapitulates aspects of congenital muscular dystrophy. Nature 418: 422-425.

Morganti MC, Taylor J, Pesheva P, Schachner M. 1990. Oligodendrocyte-derived J1-160/180 extracellular matrix glycoproteins are adhesive or repulsive depending on the partner cell type and time of interaction. Exp Neurol 109: $98-110$. 
Murgia C, Blaikie P, Kim N, Dans M, Petrie HT, Giancotti FG. 1998. Cell cycle and adhesion defects in mice carrying a targeted deletion of the integrin $\beta 4$ cytoplasmic domain. EMBO J 17: 3940-3951.

Nadarajah B, Brunstrom JE, Grutzendler J, Wong RO, Pearlman AL. 2001. Two modes of radial migration in early development of the cerebral cortex. Nat Neurosci 4: $143-150$.

Nakamoto T, Kain KH, Ginsberg MH. 2004. Neurobiology: New connections between integrins and axon guidance. Curr Biol 14: R121-123.

Nakamura H, Fujii Y, Inoki I, Sugimoto K, Tanzawa K, Matsuki H, Miura R, Yamaguchi Y, Okada Y. 2000. Brevican is degraded by matrix metalloproteinases and aggrecanase-1 (ADAMTS4) at different sites. J Biol Chem 275: 38885-38890.

Neugebauer KM, Emmett CJ, Venstrom KA, Reichardt LF. 1991. Vitronectin and thrombospondin promote retinal neurite outgrowth: Developmental regulation and role of integrins. Neuron 6: 345-358.

Nishimune H, Sanes JR, Carlson SS. 2004. A synaptic laminin-calcium channel interaction organizes active zones in motor nerve terminals. Nature 432: 580-587.

Nishimune H, Valdez G, Jarad G, Moulson CL, Muller U, Miner JH, Sanes JR. 2008. Laminins promote postsynaptic maturation by an autocrine mechanism at the neuromuscular junction. J Cell Biol 182: 1201-1215.

Niu S, Renfro A, Quattrocchi CC, Sheldon M, D’Arcangelo G. 2004. Reelin promotes hippocampal dendrite development through the VLDLR/ApoER2-Dab1 pathway. Neuron 41: 71-84.

Niu S, Yabut O, D’Arcangelo G. 2008. The Reelin signaling pathway promotes dendritic spine development in hippocampal neurons. J Neurosci 28: 10339-10348.

Noakes PG, Gautam M, Mudd J, Sanes JR, Merlie JP. 1995. Aberrant differentiation of neuromuscular junctions in mice lacking s-laminin/laminin $\beta 2$. Nature 374: $258-262$.

Noctor SC, Martinez-Cerdeno V, Kriegstein AR. 2007. Neural stem and progenitor cells in cortical development. Novartis Found Symp 288: 96-58.

O'Shea KS, Liu LH, Dixit VM. 1991. Thrombospondin and a $140 \mathrm{kd}$ fragment promote adhesion and neurite outgrowth from embryonic central and peripheral neurons and from PC12 cells. Neuron 7: 231-237.

Ogawa M, Miyata T, Nakajima K, Yagyu K, Seike M, Ikenaka K, Yamamoto H, Mikoshiba K. 1995. The reeler geneassociated antigen on Cajal-Retzius neurons is a crucial molecule for laminar organization of cortical neurons. Neuron 14: 899-912.

Olson EC, Kim S, Walsh CA. 2006. Impaired neuronal positioning and dendritogenesis in the neocortex after cell-autonomous Dab1 suppression. J Neurosci 26: 1767-1775.

Oray S, Majewska A, Sur M. 2004. Dendritic spine dynamics are regulated by monocular deprivation and extracellular matrix degradation. Neuron 44: 1021-1030.

Osterhout DJ, Frazier WA, Higgins D. 1992. Thrombospondin promotes process outgrowth in neurons from the peripheral and central nervous systems. Dev Biol 150: 256-265.
Extracellular Matrix in the Nervous System

Otto SJ, McCorkle SR, Hover J, Conaco C, Han JJ, Impey S, Yochum GS, Dunn JJ, Goodman RH, Mandel G. 2007. A new binding motif for the transcriptional repressor REST uncovers large gene networks devoted to neuronal functions. J Neurosci 27: 6729-6739.

Patton BL. 2003. Basal lamina and the organization of neuromuscular synapses. J Neurocytol 32: 883-903.

Patton BL, Cunningham JM, Thyboll J, Kortesmaa J, Westerblad H, Edstrom L, Tryggvason K, Sanes JR. 2001. Properly formed but improperly localized synaptic specializations in the absence of laminin $\alpha 4$. Nat Neurosci 4: 597-604.

Peles E, Salzer JL. 2000. Molecular domains of myelinated axons. Curr Opin Neurobiol 10: 558-565.

Peng HB, Xie H, Rossi SG, Rotundo RL. 1999. Acetylcholinesterase clustering at the neuromuscular junction involves perlecan and dystroglycan. J Cell Biol 145: 911-921.

Perris R, Perissinotto D. 2000. Role of the extracellular matrix during neural crest cell migration. Mech Dev 95: 3-21.

Pesheva P, Gennarini G, Goridis C, Schachner M. 1993. The F3/11 cell adhesion molecule mediates the repulsion of neurons by the extracellular matrix glycoprotein J1-160/180. Neuron 10: 69-82.

Pesheva P, Gloor S, Schachner M, Probstmeier R. 1997. Tenascin- $\mathrm{R}$ is an intrinsic autocrine factor for oligodendrocyte differentiation and promotes cell adhesion by a sulfatide-mediated mechanism. J Neurosci 17: 46424651.

Pesheva P, Spiess E, Schachner M. 1989. J1-160 and J1-180 are oligodendrocyte-secreted nonpermissive substrates for cell adhesion. J Cell Biol 109: 1765-1778.

Pierret C, Morrison JA, Rath P, Zigler RE, Engel LA, Fairchild CL, Shi H, Maruniak JA, Kirk MD. 2010. Developmental cues and persistent neurogenic potential within an in vitro neural niche. BMC Dev Biol 10: 5-24.

Pilgram GS, Potikanond S, Baines RA, Fradkin LG, Noordermeer JN. 2010. The roles of the dystrophin-associated glycoprotein complex at the synapse. Mol Neurobiol 41: $1-21$.

Pinto-Lord MC, Evrard P, Caviness VS Jr, 1982. Obstructed neuronal migration along radial glial fibers in the neocortex of the reeler mouse: A Golgi-EM analysis. Brain Res 256: 379-393.

Piper M, Anderson R, Dwivedy A, Weinl C, van Horck F, Leung KM, Cogill E, Holt C. 2006. Signaling mechanisms underlying Slit2-induced collapse of Xenopus retinal growth cones. Neuron 49: 215-228.

Pizzorusso T, Medini P, Berardi N, Chierzi S, Fawcett JW, Maffei L. 2002. Reactivation of ocular dominance plasticity in the adult visual cortex. Science 298: 1248-1251.

Porcionatto MA. 2006. The extracellular matrix provides directional cues for neuronal migration during cerebellar development. Braz J Med Biol Res 39: 313-320.

Pujadas L, Gruart A, Bosch C, Delgado L, Teixeira CM, Rossi D, de Lecea L, Martinez A, Delgado-Garcia JM, Soriano E. 2010. Reelin regulates postnatal neurogenesis and enhances spine hypertrophy and long-term potentiation. J Neurosci 30: 4636-4649. 


\section{C.S. Barros et al.}

Qiu S, Korwek KM, Pratt-Davis AR, Peters M, Bergman MY Weeber EJ. 2006. Cognitive disruption and altered hippocampus synaptic function in Reelin haploinsufficient mice. Neurobiol Learn Mem 85: 228-242.

Radakovits R, Barros CS, Belvindrah R, Patton B, Muller U. 2009. Regulation of radial glial survival by signals from the meninges. J Neurosci 29: 7694-7705.

Rauch U. 2004. Extracellular matrix components associated with remodeling processes in brain. Cell Mol Life Sci 61: 2031-2045.

Reichardt LF, Tomaselli KJ. 1991. Extracellular matrix molecules and their receptors: functions in neural development. Annu Rev Neurosci 14: 531-570.

Relucio J, Tzvetanova ID, Ao W, Lindquist S, Colognato H. 2009. Laminin alters fyn regulatory mechanisms and promotes oligodendrocyte development. J Neurosci 29: 11794-11806.

Relvas JB, Setzu A, Baron W, Buttery PC, LaFlamme SE, Franklin RJ, ffrench-Constant C. 2001. Expression of dominant-negative and chimeric subunits reveals an essential role for $\beta 1$ integrin during myelination. Curr Biol 11: 1039-1043.

Rigato F, Garwood J, Calco V, Heck N, Faivre-Sarrailh C, Faissner A. 2002. Tenascin-C promotes neurite outgrowth of embryonic hippocampal neurons through the alternatively spliced fibronectin type III BD domains via activation of the cell adhesion molecule F3/contactin. J Neurosci 22: 6596-6609.

Rogers JT, Weeber EJ. 2008. Reelin and apoE actions on signal transduction, synaptic function and memory formation. Neuron Glia Biol 4: 259-270.

Rolls A, Shechter R, Schwartz M. 2009. The bright side of the glial scar in CNS repair. Nat Rev Neurosci 10: 235-241.

Saghatelyan A, de Chevigny A, Schachner M, Lledo PM. 2004. Tenascin-R mediates activity-dependent recruitment of neuroblasts in the adult mouse forebrain. Nat Neurosci 7: 347-356.

Saito F, Moore SA, Barresi R, Henry MD, Messing A, RossBarta SE, Cohn RD, Williamson RA, Sluka KA, Sherman DL, et al. 2003. Unique role of dystroglycan in peripheral nerve myelination, nodal structure, and sodium channel stabilization. Neuron 38: 747-758.

Sanada K, Gupta A, Tsai LH. 2004. Disabled-1-regulated adhesion of migrating neurons to radial glial fiber contributes to neuronal positioning during early corticogenesis. Neuron 42: 197-211.

Sanes JR. 1989. Extracellular matrix molecules that influence neural development. Annu Rev Neurosci 12: $491-$ 516.

Sanes JR. 2003. The basement membrane/basal lamina of skeletal muscle. J Biol Chem 278: 12601-12604.

Schiffmann SN, Bernier B, Goffinet AM. 1997. Reelin mRNA expression during mouse brain development. Eur J Neurosci 9: 1055-1071.

Schoenherr CJ, Paquette AJ, Anderson DJ. 1996. Identification of potential target genes for the neuron-restrictive silencer factor. Proc Natl Acad Sci 93: 9881-9886.

Schwander M, Shirasaki R, Pfaff SL, Muller U. 2004. $\beta 1$ integrins in muscle, but not in motor neurons, are required for skeletal muscle innervation. J Neurosci 24: 8181-8191.
Scott-Drew S, ffrench-Constant C. 1997. Expression and function of thrombospondin-1 in myelinating glial cells of the central nervous system. J Neurosci Res 50: 202-214.

Seiradake E, von Philipsborn AC, Henry M, Fritz M, LortatJacob H, Jamin M, Hemrika W, Bastmeyer M, Cusack S, McCarthy AA. 2009. Structure and functional relevance of the Slit2 homodimerization domain. EMBO Rep 10: $736-741$.

Sheppard AM, Pearlman AL. 1997. Abnormal reorganization of preplate neurons and their associated extracellular matrix: An early manifestation of altered neocortical development in the reeler mutant mouse. J Comp Neurol 378: $173-179$.

Sherman DL, Brophy PJ. 2005. Mechanisms of axon ensheathment and myelin growth. Nat Rev Neurosci 6: 683-690.

Shorer Z, Philpot J, Muntoni F, Sewry C, Dubowitz V. 1995. Demyelinating peripheral neuropathy in merosindeficient congenital muscular dystrophy. J Child Neurol 10: $472-475$.

Shy ME. 2009. Biology of peripheral inherited neuropathies: Schwann cell axonal interactions. Adv Exp Med Biol 652: $171-181$.

Sia GM, Beique JC, Rumbaugh G, Cho R, Worley PF, Huganir RL. 2007. Interaction of the $\mathrm{N}$-terminal domain of the AMPA receptor GluR4 subunit with the neuronal pentraxin NP1 mediates GluR4 synaptic recruitment. Neuron 55: $87-102$.

Sievers J, Pehlemann FW, Gude S, Berry M. 1994. A time course study of the alterations in the development of the hamster cerebellar cortex after destruction of the overlying meningeal cells with 6-hydroxydopamine on the day of birth. J Neurocytol 23: 117-134.

Sievers J, von Knebel Doeberitz C, Pehlemann FW, Berry M. 1986. Meningeal cells influence cerebellar development over a critical period. Anat Embryol (Berl) 175: 91-100.

Sigoillot SM, Bourgeois F, Lambergeon M, Strochlic L, Legay C. 2010a. ColQ controls postsynaptic differentiation at the neuromuscular junction. J Neurosci 30: 13-23.

Sigoillot SM, Bourgeois F, Legay C. 2010b. Cholinesterases regulation in the absence of ColQ. Chem Biol Interact 187: 84-89.

Silva A, Pereira J, Oliveira CR, Relvas JB, Rego AC. 2009. BDNF and extracellular matrix regulate differentiation of mice neurosphere-derived cells into a GABAergic neuronal phenotype. J Neurosci Res 87: 1986-1996.

Silver J, Miller JH. 2004. Regeneration beyond the glial scar. Nat Rev Neurosci 5: 146-156.

Simons M, Trajkovic K. 2006. Neuron-glia communication in the control of oligodendrocyte function and myelin biogenesis. J Cell Sci 119: 4381-4389.

Simons M, Trotter J. 2007. Wrapping it up: The cell biology of myelination. Curr Opin Neurobiol 17: 533-540.

Sinagra M, Verrier D, Frankova D, Korwek KM, Blahos J, Weeber EJ, Manzoni OJ, Chavis P. 2005. Reelin, very-lowdensity lipoprotein receptor, and apolipoprotein $\mathrm{E}$ receptor 2 control somatic NMDA receptor composition during hippocampal maturation in vitro. J Neurosci 25: 6127-6136.

Smith-Thomas LC, Stevens J, Fok-Seang J, Faissner A, Rogers JH, Fawcett JW. 1995. Increased axon regeneration in 
astrocytes grown in the presence of proteoglycan synthesis inhibitors. J Cell Sci 108: 1307-1315.

Smyth N, Vatansever HS, Murray P, Meyer M, Frie C, Paulsson M, Edgar D. 1999. Absence of basement membranes after targeting the LAMC1 gene results in embryonic lethality due to failure of endoderm differentiation. J Cell Biol 144: 151-160.

Sobeih MM, Corfas G. 2002. Extracellular factors that regulate neuronal migration in the central nervous system. Int J Dev Neurosci 20: 349-357.

Stanco A, Szekeres C, Patel N, Rao S, Campbell K, Kreidberg JA, Polleux F, Anton ES. 2009. Netrin-1- $\alpha 3 \beta 1$ integrin interactions regulate the migration of interneurons through the cortical marginal zone. Proc Natl Acad Sci 106: $7595-7600$.

Stein E, Tessier-Lavigne M. 2001. Hierarchical organization of guidance receptors: silencing of netrin attraction by slit through a Robo/DCC receptor complex. Science 291: 1928-1938.

Stevens B. 2008. Neuron-astrocyte signaling in the development and plasticity of neural circuits. Neurosignals 16: $278-288$.

Strekalova T, Sun M, Sibbe M, Evers M, Dityatev A, Gass P, Schachner M. 2002. Fibronectin domains of extracellular matrix molecule tenascin- $\mathrm{C}$ modulate hippocampal learning and synaptic plasticity. Mol Cell Neurosci 21: 173-187.

Strochlic L, Cartaud A, Cartaud J. 2005. The synaptic muscle-specific kinase (MuSK) complex: New partners, new functions. Bioessays 27: 1129-1135.

Sun YM, Cooper M, Finch S, Lin HH, Chen ZF, Williams BP, Buckley NJ. 2008. Rest-mediated regulation of extracellular matrix is crucial for neural development. PLoS One 3: e3656.

Talts JF, Andac Z, Gohring W, Brancaccio A, Timpl R. 1999. Binding of the $\mathrm{G}$ domains of laminin $\alpha 1$ and $\alpha 2$ chains and perlecan to heparin, sulfatides, $\alpha$-dystroglycan and several extracellular matrix proteins. EMBO J 18: $863-$ 870.

Taylor J, Pesheva P, Schachner M. 1993. Influence of janusin and tenascin on growth cone behavior in vitro. J Neurosci Res 35: 347-362.

Temple S. 2001. The development of neural stem cells. Nature 414: 112-117.

Timpl R, Brown JC. 1996. Supramolecular assembly of basement membranes. Bioessays 18: 123-132.

Timpl R, Rohde H, Robey PG, Rennard SI, Foidart JM, Martin GR. 1979. Laminin-a glycoprotein from basement membranes. J Biol Chem 254: 9933-9937.

Tomaselli KJ, Reichardt LF. 1988. Peripheral motoneuron interactions with laminin and Schwann cell-derived neurite-promoting molecules: Developmental regulation of laminin receptor function. J Neurosci Res 21: 275-285.

Tomaselli KJ, Hall DE, Flier LA, Gehlsen KR, Turner DC, Carbonetto S, Reichardt LF. 1990. A neuronal cell line (PC12) expresses two $\beta 1$-class integrins- $\alpha 1 \beta 1$ and $\alpha 3$ $\beta 1$-that recognize different neurite outgrowth-promoting domains in laminin. Neuron 5: 651-662.

Treloar HB, Ray A, Dinglasan LA, Schachner M, Greer CA. 2009. Tenascin-C is an inhibitory boundary molecule in the developing olfactory bulb. J Neurosci 29: $9405-$ 9416.

Trommsdorff M, Gotthardt M, Hiesberger T, Shelton J, Stockinger W, Nimpf J, Hammer RE, Richardson JA, Herz J. 1999. Reeler/Disabled-like disruption of neuronal migration in knockout mice lacking the VLDL receptor and ApoE receptor 2. Cell 97: 689-701.

Tucker RP. 2004. The thrombospondin type 1 repeat superfamily. Int J Biochem Cell Biol 36: 969-974.

Tzarfati-Majar V, Burstyn-Cohen T, Klar A. 2001. F-spondin is a contact-repellent molecule for embryonic motor neurons. Proc Natl Acad Sci 98: 4722-4727.

Ullian EM, Sapperstein SK, Christopherson KS, Barres BA. 2001. Control of synapse number by glia. Science 291: 657-661.

Venstrom KA, Reichardt LF. 1993. Extracellular matrix. 2: Role of extracellular matrix molecules and their receptors in the nervous system. FASEB J 7: 996-1003.

von Holst A. 2008. Tenascin C in stem cell niches: redundant, permissive or instructive? Cells Tissues Organs 188: $170-177$.

von Holst A, Sirko S, Faissner A. 2006. The unique 473HD-Chondroitinsulfate epitope is expressed by radial glia and involved in neural precursor cell proliferation. $J$ Neurosci 26: 4082-4094.

von Knebel Doeberitz C, Sievers J, Sadler M, Pehlemann FW, Berry M, Halliwell P. 1986. Destruction of meningeal cells over the newborn hamster cerebellum with 6hydroxydopamine prevents foliation and lamination in the rostral cerebellum. Neurosci 17: 409-426.

Wallquist W, Plantman S, Thams S, Thyboll J, Kortesmaa J, Lannergren J, Domogatskaya A, Ogren SO, Risling M, Hammarberg $\mathrm{H}$, et al. 2005. Impeded interaction between Schwann cells and axons in the absence of laminin alpha4. J Neurosci 25: 3692-3700.

Weber P, Bartsch U, Rasband MN, Czaniera R, Lang Y, Bluethmann H, Margolis RU, Levinson SR, Shrager P, Montag D, et al. 1999. Mice deficient for tenascin-R display alterations of the extracellular matrix and decreased axonal conduction velocities in the CNS. J Neurosci 19: $4245-4262$.

Weeber EJ, Beffert U, Jones C, Christian JM, Forster E, Sweatt JD, Herz J. 2002. Reelin and ApoE receptors cooperate to enhance hippocampal synaptic plasticity and learning. J Biol Chem 277: 39944-39952.

Werle MJ. 2008. Cell-to-cell signaling at the neuromuscular junction: the dynamic role of the extracellular matrix. Ann N Y Acad Sci 1132: 13-18.

Wu H, Xiong WC, Mei L. 2010. To build a synapse: Signaling pathways in neuromuscular junction assembly. Development 137: 1017-1033.

Xu J, Xiao N, Xia J. 2010. Thrombospondin 1 accelerates synaptogenesis in hippocampal neurons through neuroligin 1. Nat Neurosci 13: 22-24.

Xu D, Hopf C, Reddy R, Cho RW, Guo L, Lanahan A, Petralia RS, Wenthold RJ, O'Brien RJ, Worley P. 2003. Narp and NP1 form heterocomplexes that function in developmental and activity-dependent synaptic plasticity. Neuron 39: 513-528.

Yamaguchi Y. 2000. Lecticans: organizers of the brain extracellular matrix. Cell Mol Life Sci 57: 276-289. 


\section{C.S. Barros et al.}

Yang D, Bierman J, Tarumi YS, Zhong YP, Rangwala R, Proctor TM, Miyagoe-Suzuki Y, Takeda S, Miner JH, Sherman LS, et al. 2005. Coordinate control of axon defasciculation and myelination by laminin-2 and -8. J Cell Biol 168: 655-666.

Yick LW, Cheung PT, So KF, Wu W. 2003. Axonal regeneration of Clarke's neurons beyond the spinal cord injury scar after treatment with chondroitinase ABC. Exp Neurol 182: $160-168$.

Yonezawa T, Hattori S, Inagaki J, Kurosaki M, Takigawa T, Hirohata S, Miyoshi T, Ninomiya Y. 2010. Type IV collagen induces expression of thrombospondin- 1 that is mediated by integrin alphalbetal in astrocytes. Glia 58: $755-767$.

Yoshida A, Kobayashi K, Manya H, Taniguchi K, Kano H, Mizuno M, Inazu T, Mitsuhashi H, Takahashi S, Takeuchi M, et al. 2001. Muscular dystrophy and neuronal migration disorder caused by mutations in a glycosyltransferase, POMGnT1. Dev Cell 1: 717-724.

Yoshimura T, Kawano Y, Arimura N, Kawabata S, Kikuchi A, Kaibuchi K. 2005. GSK-3 $\beta$ regulates phosphorylation of CRMP-2 and neuronal polarity. Cell 120: 137-149.
Young-Pearse TL, Bai J, Chang R, Zheng JB, LoTurco JJ, Selkoe DJ. 2007. A critical function for beta-amyloid precursor protein in neuronal migration revealed by in utero RNA interference. J Neurosci 27: 1445914469.

Ypsilanti AR, Zagar Y, Chedotal A. 2010. Moving away from the midline: new developments for Slit and Robo. Development 137: 1939-1952.

Yu WM, Yu H, Chen ZL. 2007. Laminins in peripheral nerve development and muscular dystrophy. Mol Neurobiol 35: 288-297.

Yu WM, Feltri ML, Wrabetz L, Strickland S, Chen ZL. 2005. Schwann cell-specific ablation of laminin gammal causes apoptosis and prevents proliferation. J Neurosci 25: 4463-4472.

Zhang B, Luo S, Wang Q, Suzuki T, Xiong WC, Mei L. 2008. LRP4 serves as a coreceptor of agrin. Neuron 60: 285 297.

Zimmermann DR, Dours-Zimmermann MT. 2008. Extracellular matrix of the central nervous system: From neglect to challenge. Histochem Cell Biol 130: 635-653. 


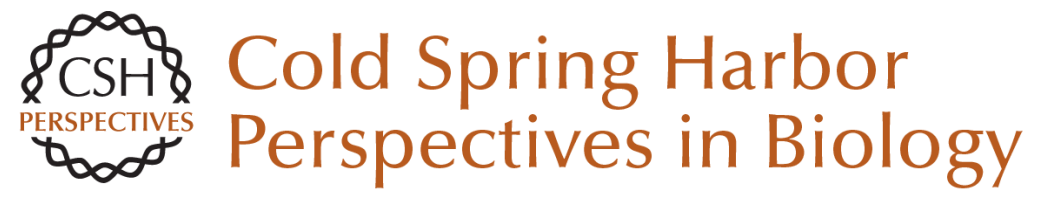

\section{Extracellular Matrix: Functions in the Nervous System}

Claudia S. Barros, Santos J. Franco and Ulrich Müller

Cold Spring Harb Perspect Biol 2011; doi: 10.1101/cshperspect.a005108 originally published online December 1, 2010

\section{Subject Collection Extracellular Matrix Biology}

Extracellular Matrix in Development: Insights from Mechanisms Conserved between Invertebrates and Vertebrates Nicholas H. Brown

Extracellular Matrix Proteins in Hemostasis and Thrombosis Wolfgang Bergmeier and Richard O. Hynes

The Thrombospondins Josephine C. Adams and Jack Lawler

Cross Talk among TGF- $\beta$ Signaling Pathways, Integrins, and the Extracellular Matrix John S. Munger and Dean Sheppard

Heparan Sulfate Proteoglycans Stephane Sarrazin, William C. Lamanna and Jeffrey D. Esko

The Collagen Family Sylvie Ricard-Blum

Tenascins and the Importance of Adhesion Modulation

Ruth Chiquet-Ehrismann and Richard P. Tucker

Integrin Structure, Activation, and Interactions

lain D. Campbell and Martin J. Humphries
Extracellular Matrix Degradation and Remodeling in Development and Disease

Pengfei Lu, Ken Takai, Valerie M. Weaver, et al.

Overview of the Matrisome--An Inventory of Extracellular Matrix Constituents and Functions Richard O. Hynes and Alexandra Naba

Integrins in Cell Migration Anna Huttenlocher and Alan Rick Horwitz

Fibronectins, Their Fibrillogenesis, and In Vivo

Functions Jean E. Schwarzbauer and Douglas W. DeSimone

Extracellular Matrix: Functions in the Nervous System

Claudia S. Barros, Santos J. Franco and Ulrich Müller

Molecular Architecture and Function of Matrix

Adhesions

Benjamin Geiger and Kenneth M. Yamada

Cell-Extracellular Matrix Interactions in Normal and Diseased Skin

Fiona M. Watt and Hironobu Fujiwara

Genetic Analyses of Integrin Signaling

Sara A. Wickström, Korana Radovanac and Reinhard Fässler

For additional articles in this collection, see http://cshperspectives.cshlp.org/cgi/collection/

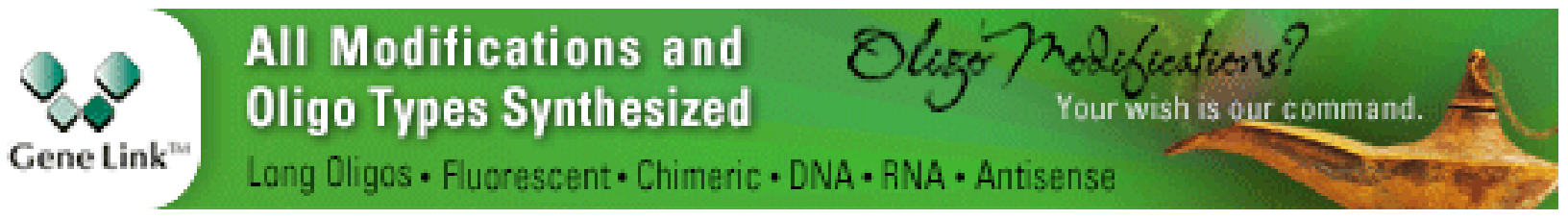

Copyright @ 2011 Cold Spring Harbor Laboratory Press; all rights reserved 